\title{
O ENSINO-APRENDIZAGEM DE MATEMÁTICA POR MEIO DE PROJETOS ENVOLVENDO PROFISSÕES: UM ESTUDO DE CASO NO ENSINO FUNDAMENTAL
}

\section{TEACHING LEARNING MATHEMATICS THROUGH PROJECTS INVOLVING PROFESSIONS: A CASE STUDY IN ELEMENTARY SCHOOL}

\author{
Rudnei Nunes Pego, Vanessa Battestin Nunes * \\ Instituto Federal do Espírito Santo $\left({ }^{*}\right)$ \\ Centro de Referência em Formação e Educação a Distância (CEFOR) \\ Rodovia ES-010 - s/n. Manguinhos - Serra, Espírito Santo. \\ E-mail: vanessa@ifes.edu.br
}

\section{Resumo}

Este artigo mostra uma proposta de ensino-aprendizagem de alguns conhecimentos de matemática por meio de projetos relacionados a uma profissão. Foi realizado um estudo de caso com duas turmas do 9o ano do ensino fundamental de uma escola pública municipal da Serra-ES, envolvendo as profissões de Arquitetura e Engenharia, escolhidas com as turmas, em que foram trabalhados os conteúdos de Trigonometria no Triângulo Retângulo e Áreas de Figuras Planas. 0 projeto ficou definido como: a construção de uma maquete da escola e plantas baixas da escola e da praça, em escala. Os resultados foram positivos: alunos mais comprometidos e motivados; aumentou a autoestima; diminuiu a resistência à Matemática e a distância entre teoria e prática; e melhorou sensivelmente o desempenho dos alunos.

Palavras-chave: ensino-aprendizagem, trigonometria, áreas de figuras planas, aprendizagem baseada em projetos

\begin{abstract}
This article shows a teaching-learning of some knowledge of mathematics through projects related to a profession. It was performed a case study with two classes of 9th grade of elementary education in a public school of Serra-ES, involving the professions of Architecture and Engineering, chosen with the classes, in which the contents of Trigonometry in the Rectangle Triangle and Areas of Plane Figures were worked. The project was defined as: the construction of a maquette of the school and floor plans of the school and the plaza, in scale. The results were positive: more engaged and motivated students; increased self-esteem; decreased resistance to mathematics and the distance between theory and practice; and improved significantly the performance of students.
\end{abstract}

Keywords: teaching-learning, trigonometry, areas of plane figures, project-based learning 


\section{INTRODUÇÃO}

A Matemática é uma ciência extremamente importante para qualquer cidadão. Ela está presente quando uma dona de casa prepara um prato cuja receita pede, por exemplo, $1 / 2$ xícara de trigo e 3/4 de xícara de leite. Também está presente quando um pedreiro irá assentar o piso de uma casa e precisa calcular a área $\left(\mathrm{m}^{2}\right)$, para saber a quantidade necessária de piso, argamassa e rejunte. Ou quando um casal se prepara para comprar a sonhada casa própria e precisa calcular os juros, prestações, taxas e demais valores referentes ao preço do imóvel.

Porém, apesar da sua inegável necessidade, o ensino-aprendizagem da Matemática tem sido um desafio constante para alunos e professores. Os alunos muitas vezes não conseguem entender o que o professor ensina. O professor, mesmo usando métodos diferentes, não obtém muito sucesso, pois encontra problemas dentro ou fora da escola, como: precariedade do espaço escolar, alunos desmotivados, sem apoio da família etc. A sensação do professor é a de que o aluno não quer aprender e a sensação do aluno é de que ele é incapaz de aprender ou de que o professor não sabe ensinar.

Isso tem refletido em pesquisas, que mostram uma realidade ruim para a Matemática no Brasil. É o caso da avaliação PISA (Programa Internacional de Avaliação de Alunos), realizada a cada três anos pela Organização para a Cooperação e Desenvolvimento Econômico (OCDE). Apesar de ter havido uma melhora em Matemática nos últimos anos, o Brasil ainda está entre os piores do mundo, tendo ocupado o $58^{\circ}$ lugar de 65 países, na avaliação de 2012. Com a pontuação de 391, o Brasil se manteve no nível 1 de aprendizagem, em uma escala de 1 a 6 , sendo 1 o pior. Isso quer dizer que os alunos conseguem apenas localizar informações explícitas e não são capazes de fazer comparações, estabelecer conexões ou interpretar textos (INEP, 2012).

Araújo (2007, p.1) aponta possíveis razões para o mau desempenho em Matemática:

Os alunos gostam de ser desafiados, porém, a precariedade das condições de ensino e os equívocos de determinadas orientações pedagógicas, muitas vezes, tornam o ensino da Matemática algo desinteressante e vago, não despertando nos alunos a importância necessária para o seu aprendizado. 
A Matemática, frequentemente, é ensinada de forma expositiva, sem demonstrar sua real utilização em situações corriqueiras das vidas das pessoas, numa concepção bancária, como diria Paulo Freire, presa à memorização de símbolos e fórmulas. Essa forma de ensino ignora os recursos da curiosidade, da experimentação e da concretização. Exige o exercício da memória sem a vantagem da compreensão. Assim, muitas vezes, o aluno não se motiva a aprender.

Motivar o aluno mostra-se, dessa forma, como uma importante tarefa. Como cita Boruchovitch apud Sugimoto (2009, p.1), "O aluno intrinsecamente motivado realiza a tarefa pelo simples prazer, porque se interessa por ela e se satisfaz verdadeiramente com a atividade em si". Já Solé (2003) afirma que quando alguém pretende aprender e aprende, a experiência vivida Ihe oferece uma imagem positiva de si mesmo e sua autoestima é reforçada, o que constitui uma boa bagagem para continuar os desafios que se apresentam. Para Freire, a motivação tem relação com curiosidade, que se inicia de forma ingênua, passa a crítica, até se tornar epistemológica.

O processo de ensinar - no qual o ensinante desafia o educando a apreender o objeto para aprendê-lo em suas relações - implica o exercício da percepção crítica, de suas razões de ser. Implica o aguçamento da curiosidade epistemológica do educando que não pode satisfazer-se com a mera descrição do conceito de objeto (FREIRE, 1996, p.94).

Assim, cabe ao professor criar mecanismos que favoreçam a curiosidade, levando os alunos a ter maior interesse e motivação para o aprendizado da disciplina. Freire dá importantes indicações de que para isso é necessário relacionar os conteúdos a contextos práticos de sua utilização, o que também é reforçado nos PCN-MATEMÁTICA:

O estabelecimento de relações é fundamental para que o aluno compreenda efetivamente os conteúdos matemáticos, pois, abordados de forma isolada, eles não se tornam uma ferramenta eficaz para resolver problemas e para a aprendizagem/construção de novos conceitos (1998, p. 37).

Porém, Freire afirma que não adianta relacionar a teoria com qualquer situação prática, pois dispensar o conhecimento prévio e a situação social dos alunos é, muitas vezes, tornar inútil o que é ensinado. Assim, o professor deve procurar alternativas que relacionem os conteúdos com a realidade dos alunos e com suas aspirações. Uma importante estratégia é envolvê-los em atividades práticas, para que apliquem os conteúdos ensinados, dentro de seu contexto de vida: "o conhecimento não deve ser só transferido, também testemunhado e vivido, para que o aluno se envolva com motivação e eficácia" (FREIRE, 1996, p.21). D’Ambrósio (2009) também afirma que 
a ação gera a capacidade de explicar, de lidar, de manejar e de entender a realidade. Mas como o professor pode trabalhar a matemática, de forma que ela seja atrativa, que relacione teoria e prática, que desperte a curiosidade e motive os alunos para o seu aprendizado?

Uma alternativa para pensarmos nessa problemática pode ser encontrada na pedagogia de projetos. Segundo Huber (1999), a pedagogia de projetos dos alunos começa a se delinear na obra de Jean-Jacques Rousseau, quando ele deseja que seu personagem Emile aprenda não através dos livros, mas através das coisas, sugerindo que uma hora de trabalho valha mais que um dia de explicações. A estruturação do conceito de projeto passa, também, por vários outros autores, como pelo filósofo e psicólogo americano John Dewey, pelo educador francês Celestin Freinet, pelos pesquisadores Henri Wallon e Jean Piaget, até chegar ao já citado educador brasileiro Paulo Freire, que deu uma dimensão de emancipação social ao aprendizado (HUBER, 1999).

A pedagogia de projetos permite a construção coletiva de um saber ou de um conhecimento novo, através da desestabilização das representações iniciais dos membros da equipe e da construção de um novo equilíbrio em um nível superior. Segundo Piaget (1977), quando ocorre essa desestabilização o sujeito tenta encontrar os motivos de sua ocorrência, o que o leva à tomada de consciência das regiões mais centrais da ação, isto é, dos meios empregados para realizá-la. A tomada de consciência é um processo que reconstrói. É a passagem dos esquemas de ação para a conceituação, o que permitirá o sujeito alcançar um resultado favorável. O americano William H. Kilpatrick desenvolveu o "método de projetos", tendo como princípios (FÁVERO e NUNES, 2011):

a situação problemática - o projeto se inicia a partir de um problema que interessa ao aluno, ou seja, que ele está motivado a resolver;

a experiência real anterior - uma vez que esta aumenta a possibilidade do êxito;

a eficácia social - a convivência harmoniosa, colaboração e cooperação, entre os alunos deve ser um de seus objetivos.

Desta forma, a aprendizagem por projetos oferece aos alunos a oportunidade de aprender a trabalhar em grupo e realizar tarefas comuns. Exige que os alunos monitorem seu próprio desempenho e suas contribuições ao grupo, além de confrontar problemas inesperados e descobrir como resolvê-los (MARKHAM et al, 2008). Nesta forma de ensino-aprendizagem, os alunos possuem tempo para pesquisar, discutir ou construir com o grupo os resultados 
encontrados, o que tende a motivá-los, transformando as atividades em um ato de prazer e não de obrigação.

Existem evidências de que a aprendizagem por projetos melhora a qualidade da aprendizagem e leva a um desenvolvimento cognitivo de nível superior por meio do envolvimento dos alunos em problemas novos e complexos. Além disso, ensina aos alunos processos e procedimentos complexos tais como planejamento e comunicação e tende a produzir melhorias no desempenho acadêmico (MARKHAM et al, 2008).

A pedagogia de projetos estimula a interação entre os alunos e estes com o professor. Conforme cita Vygotsky, as mudanças que ocorrem em cada um de nós têm sua raiz na sociedade e na cultura. Ou seja, a aprendizagem sempre inclui relações entre as pessoas. Não há como aprender e apreender o mundo se não tivermos o outro, aquele que nos fornecem os significados que permitem pensar o mundo a nossa volta (BOCK et al., 2008). Desta forma, Vygotsky estabeleceu um importante conceito - a Zona de Desenvolvimento Proximal (ZDP) que é:

[...] a distância entre o nível de desenvolvimento real, que se costuma determinar por meio da solução independente de problemas, e o nível potencial, determinado por meio da solução de problemas sob a orientação de um adulto ou em colaboração com companheiros mais capazes (VYGOTSKY, 1994, p. 97).

Neste conceito fica clara a importância dos sujeitos que agem como mediadores do aprendizado dos alunos, que podem ser tanto os professores como os próprios colegas de sala. Assim, o ensino por meio de projetos pode ser um caminho para se alcançar a aprendizagem, uma vez que possibilita o trabalho em grupo e as mais diversas interações sociais; instiga a curiosidade e a motivação dos alunos, colocando-os em situações que são de seu interesse; além de possibilitar a construção de novos conhecimentos.

O objetivo deste trabalho foi elaborar uma possibilidade de ensino/aprendizagem de alguns conteúdos de matemática, de uma determinada série (ano), aplicá-la por meio de projetos práticos relacionados a uma profissão de interesse da turma e analisar os resultados obtidos. Visava-se, assim, a aumentar a motivação dos alunos em aprender a Matemática; possibilitar a melhoria do ensino/aprendizagem e, consequentemente, do rendimento dos alunos; estimular o trabalho em equipe, na busca de soluções para os problemas; melhorar as relações entre aluno- 
professor e aluno-aluno e aumentar a autoestima dos alunos.

\section{PERCURSO METODOLÓGICO}

Para realização deste trabalho, foi utilizada a metodologia de estudo de caso, que, como cita Gil (2002), é uma abordagem qualitativa voltada para o estudo profundo e exaustivo de um ou poucos objetos, de maneira que permita seu detalhado conhecimento. $\mathrm{O}$ estudo de caso aqui se configura como aplicação de conteúdos de trigonometria no triângulo retângulo e áreas de figuras planas a duas turmas da $8^{a}$ série do ensino fundamental ( $9^{\circ}$ ano), de uma escola pública municipal, por meio de projetos relacionados a uma profissão. Um dos autores do presente trabalho é também o professor das turmas selecionadas.

Os responsáveis dos respectivos alunos assinaram um termo de consentimento livre e esclarecido, onde concordam com a utilização dos registros coletados (imagem e texto) para realização do trabalho e possíveis publicações em eventos ou periódicos. Da mesma forma, a direção da escola assinou um documento permitindo a realização do trabalho em suas dependências.

Para isto, foram realizadas as seguintes etapas:

1a Etapa - Levantamento com os alunos - O objetivo desta etapa foi dividir os alunos em grupos para que pudessem pesquisar sobre profissões de seu interesse e, posteriormente, definirem, com o professor, a profissão que seria trabalhada no projeto.

2a Etapa - Elaboração - O objetivo desta etapa foi o professor/pesquisador elaborar os conteúdos que seriam trabalhados, de acordo com a profissão selecionada pela turma, por meio de um projeto prático. Pesquisas sobre estas profissões e a utilização da Matemática nas mesmas foram necessárias, assim como a definição dos pré-requisitos.

3a Etapa - Execução - Nesta etapa foi executado o que foi previamente planejado. O professor fez avaliações diagnósticas para identificar o nível de conhecimentos dos alunos sobre os prérequisitos necessários e trabalhou alguns aspectos, quando foi preciso. A seguir, foi realizada nova divisão dos grupos e estes realizaram a pesquisa de campo, com o auxílio do professor. Diversos momentos em sala de aula também foram necessários. A turma foi avaliada de acordo com os conteúdos trabalhados.

4a Etapa - Análise - Nesta etapa foram realizadas as análises do que foi produzido pelos alunos, de suas avaliações e do que foi coletado e observado pelo professor durante a execução do projeto. O objetivo foi verificar se esta abordagem de trabalho contribuiu no aprendizado dos alunos, as dificuldades encontradas e sugestões de melhoria. 
Para realização deste trabalho, vários procedimentos foram utilizados, como pesquisa bibliográfica sobre o método de projetos e os conteúdos a serem abordados; levantamentos realizados com os alunos; observações no decorrer da realização dos projetos, entre outros. As análises realizadas foram baseadas na abordagem do conteúdo, da perspectiva do recorte teórico aqui apresentado.

\subsection{Contexto da pesquisa}

A pesquisa foi realizada na Escola Municipal de Ensino Fundamental (EMEF) Professor Luiz Baptista, localizado em Jardim Tropical no município da Serra, Espírito Santo. Os alunos são oriundos, em quase sua totalidade, do próprio bairro ou bairros adjacentes, que são, em sua maioria, providos de pessoas carentes, de baixo poder aquisitivo, que vivenciam um alto índice de violência, gerada principalmente pelo tráfico de droga, causando, por diversas vezes, o fechamento da escola, por exemplo, quando algum líder do tráfico é assassinado (o chamado "toque de recolher").

Devido a essa realidade, diversos problemas provocam, muitas vezes, uma inversão de valores. Por exemplo, determinados alunos consideram como referencial a ser seguido pessoas que estão ligadas, direta ou indiretamente, ao tráfico. Outro exemplo são alguns responsáveis pelos alunos, que não participam de sua vida escolar, por não julgarem isso importante. 0 reflexo desse abandono e o meio em que esses alunos vivem contribuem bastante para o alto índice de reprovação e evasão escolar (desistência) em todas as séries da quinta (sexto ano) a oitava (nono ano). Também é comum o assassinato ou prisão de alguns alunos, devido ao seu envolvimento com o tráfico. Decorrem desses problemas alunos desmotivados e com defasagem de conhecimentos básicos para suas respectivas séries (ano), o que dificulta o ensino de novos conteúdos que dependem desses conhecimentos prévios.

Esses e outros motivos colaboram para que grande parte dos alunos não acredite na escola como um caminho a ser trilhado para oportunidades melhores, pois julgam que os conteúdos abordados não serão úteis em sua vida. Daí a importância desse projeto em dar oportunidade para o aluno vivenciar o conhecimento com a prática e ter uma visão mais ampla do que a que estava habituado. Na realização deste trabalho foram utilizados os próprios ambientes da escola e suas adjacências. Além disso, foi realizada uma visita técnica a um canteiro de obra. 


\subsection{Sujeitos da pesquisa}

O projeto foi executado com duas turmas da oitava série (nono ano), com 21 alunos cada. Em ambas, a quantidade de alunos desinteressados ou com dificuldade em matemática era elevada.

\subsection{Perfil dos sujeitos da pesquisa}

Por meio de um questionário aplicado aos alunos, foi identificado que $64 \%$ são do gênero feminino e $35 \%$ do masculino. $58 \%$ tem 15 anos ou mais, o que significa que mais da metade da turma está com defasagem em idade/série, já que o mais normal seria estariam completando 14 anos. $89 \%$ relataram que moram próximo à escola, o que facilitou o encontro dos alunos com os seus respectivos grupos, no presente projeto.

O Gráfico 1 mostra que aproximadamente quarenta por cento dos alunos convivem com muitas pessoas (cinco ou mais) em um mesmo domicílio. Como se trata de uma região carente, isso pode indicar que o aluno não tinha um ambiente suficientemente adequado para os estudos em casa, com silêncio, por exemplo. O Gráfico 2 mostra que quase setenta por cento das famílias dos alunos vivem com uma renda igual ou menor do que dois salários mínimos, o que evidencia a carência das mesmas. O Gráfico 3 chama atenção para a grande quantidade de alunos que estudam menos de uma hora diária (78\%), considerando não apenas Matemática, mas todas as disciplinas.

Gráfico 1 - Quantidade de pessoas que residem na mesma casa que o aluno.

Numero de pessoas que moram na mesma casa que você (incluindo você)?

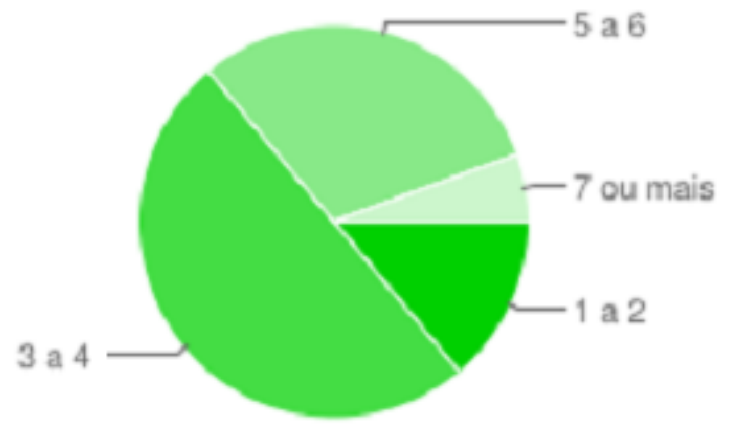

$\begin{array}{lr}1 \text { a } 2 & 14 \% \\ 3 \text { a } 4 & 50 \% \\ 5 \text { a } 6 & 31 \% \\ 7 \text { ou mais } & 6 \%\end{array}$

Fonte: O autor, por meio de questionário aplicado aos alunos (2012). 
Gráfico 2 - Renda familiar dos alunos.

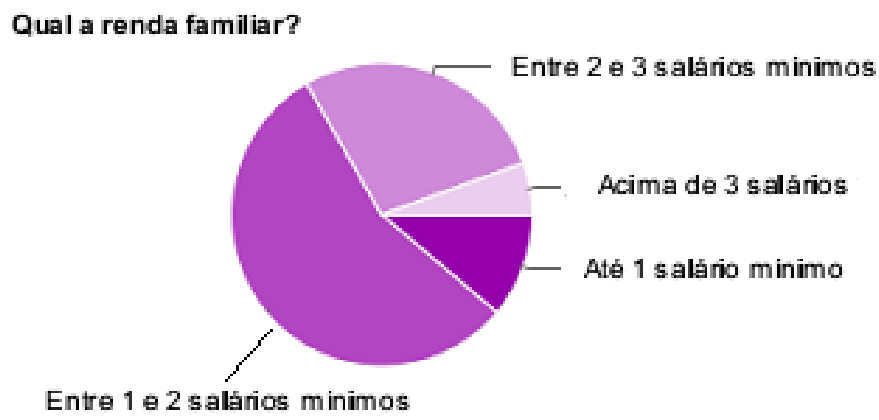

Até 1 salário minimo

Entre 1 e 2 salários minimos

Entre 2 e 3 salários minimos

Acima de 3 salários minimos
$11 \%$

$56 \%$

$28 \%$

$6 \%$

Fonte: O autor, por meio de questionário aplicado aos alunos (2012).

Gráfico 3 - Dedicação aos estudos pelos alunos.

Quantas horas por dia você dedica aos estudos (excluindo o periodo em que você tem aula)?

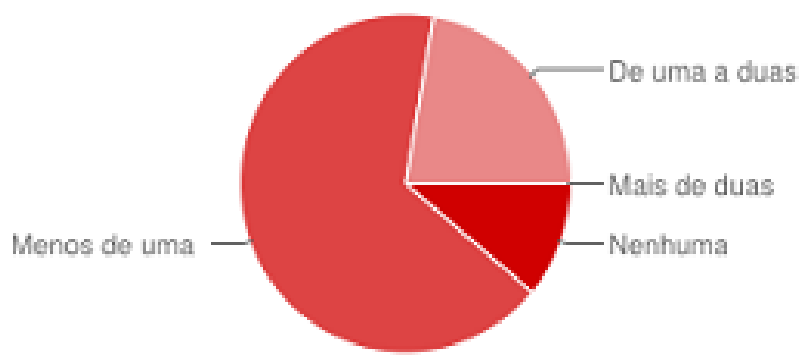

$\begin{array}{lr}\text { Nenhuma } & 11 \% \\ \text { Menos de uma } & 67 \% \\ \text { De uma a duas } & 22 \% \\ \text { Mais de duas } & 0 \%\end{array}$

Fonte: O autor, por meio de questionário aplicado aos alunos (2012).

\subsection{Recursos utilizados na pesquisa}

Em muitos momentos foi necessário medir a escola e outros espaços para conhecer sua dimensão e sua área construída. Para isso, utilizou-se o teodolito (construído pelos alunos) e a trena. Em sala de aula foi utilizado quadro, pincel e projetor, tanto para aulas expositivas, como para apresentações pelos alunos. O laboratório de informática também foi utilizado, para realizar pesquisas, além da sala de vídeo, onde os alunos tiveram contado com a profissão escolhida. Durante a pesquisa de campo e nos momentos em sala de aula, o professor fez registros através de fotografias, filmagens e anotações. Os alunos também realizaram registros, em seus respectivos relatórios. 


\section{RESULTADOS E DISCUSSÃO}

Nessa seção são descritos os resultados do presente trabalho e as análises realizadas, que ocorreram, como já citado, mediante a realização das etapas de Levantamento com os alunos, Elaboração, Execução e Análise.

\subsection{Etapa - Levantamento com os alunos}

Os alunos foram divididos em grupos de quatro pessoas, com exceção de alguns que ficaram com cinco. Cada grupo escolheu, de forma livre, profissões de seu interesse e, em seguida, fizeram pesquisas sobre a profissão escolhida, mostrando a importância da matemática nela. Os grupos trabalharam com maquetes, desenhos, computador e outros objetos concretos que, além de motivadores, iniciaram o envolvimento dos alunos com o projeto.

Posteriormente, foi montada uma pequena exposição na escola, para que os grupos pudessem mostrar suas produções, inclusive para o público externo, como mostra a Figura 1. A motivação da maioria dos grupos era grande, por poder explicar para as pessoas o que havia sido construído por eles. Alguns tiveram a oportunidade de ouvir experiências de pessoas da comunidade que trabalham nas profissões que estavam sendo expostas e foi gratificante perceber que o que eles fizeram tinha, em parte, uma relação direta com que os profissionais fazem.

Figura 1. Fotos da apresentação dos alunos sobre profissões.
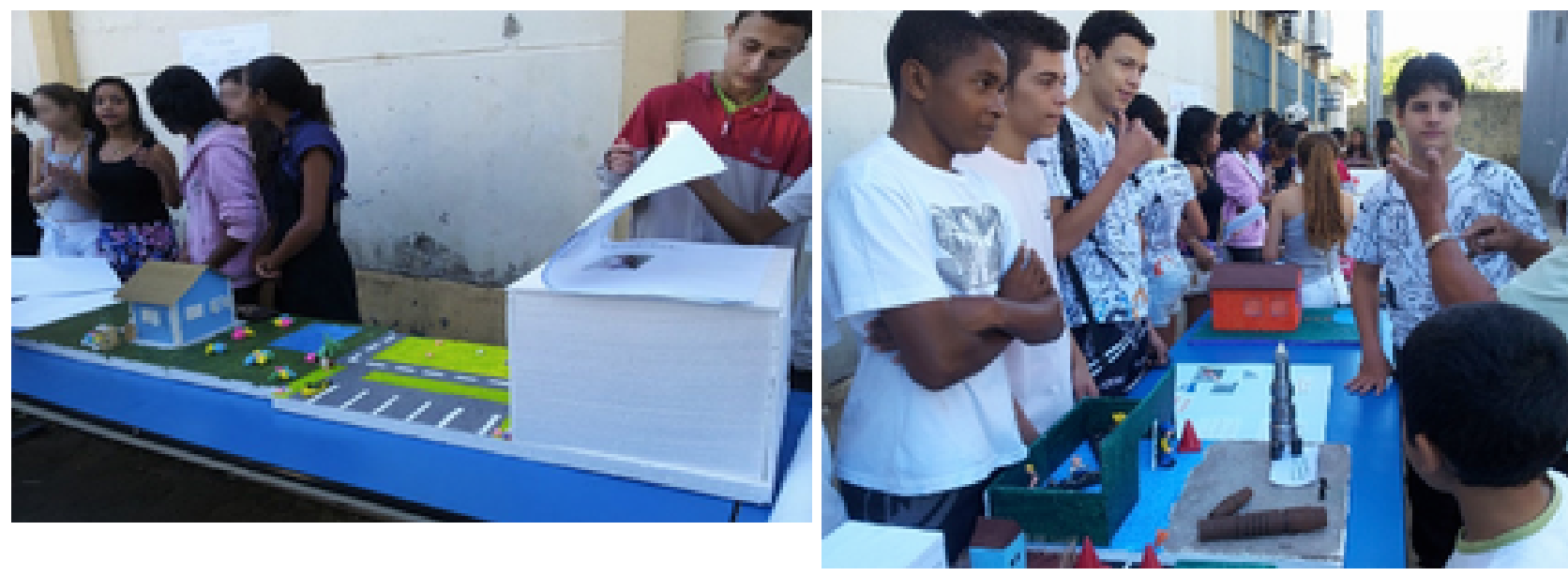

Fonte: O autor, na escola (2012). 
Todos os grupos cumpriram o que foi proposto, apesar de haver três alunos, de grupos diferentes, que, na opinião do professor, destoavam em relação aos outros componentes de seus respectivos grupos, aparentando não haver cumprido a contento sua parte no trabalho. Nesta etapa, os alunos tiveram a oportunidade de escolher as profissões e produzir materiais que explicassem um pouco das mesmas, informando os conteúdos matemáticos que foram utilizados. Neste momento, porém, não era cobrado dos alunos que entendessem dos conteúdos que estavam falando nem de escalas para as maquetes ou plantas que foram produzidas. O importante foi perceber, tanto pelo professor e principalmente pelos próprios alunos, que eles eram capazes de produzir algo que não era comum no cotidiano escolar. "O conhecimento exige uma presença curiosa do sujeito em face do mundo. Requer uma ação transformadora sobre a realidade. Demanda uma busca constante. Implica em invenção e em reinvenção (FREIRE, 1983, p. 27)".

Ao fim desta primeira etapa, o professor e os alunos escolheram as profissões Engenharia Civil e Arquitetura, que foram as que mais apareceram nas apresentações e que eles demonstraram maior interesse. Vale destacar que para este trabalho, essas profissões serão consideradas como se fossem uma só e serão representadas pela escrita Arquitetura/Engenharia Civil. Esta fase foi importante, pois na sequência do trabalho dos alunos haveria necessidade de construir novas maquetes e plantas baixas que não seriam mais novidades para alguns alunos. Além disso, percebendo que eram capazes de realizar tarefas com que não estavam habituados, os alunos mostravam-se mais empenhados para as próximas fases do projeto. Inclusive, os alunos tímidos, que não costumavam apresentar trabalho expositivo, impulsionados pelo compromisso firmado com os colegas de grupo e o interesse pela profissão, conseguiram se expressar durante a exposição.

\subsection{Etapa - Elaboração}

Nesta etapa, foi planejado um projeto prático, de acordo com a profissão selecionada pela turma, elaborando os conteúdos que seriam trabalhados. Como a profissão definida pelas turmas foi Arquitetura/Engenharia Civil, conteúdos de trigonometria no triângulo retângulo e cálculo de áreas de figuras planas mostraram-se interessantes de serem trabalhados, uma vez que são normalmente abordados nas oitavas séries (turmas escolhidas no estudo de caso) e são usados com boa frequência nesta profissão. Além disso, pela experiência prévia do professor, eram 
conteúdos que os alunos, geralmente, apresentavam dificuldades. Portanto, foram estes os escolhidos. Foram realizadas algumas pesquisas sobre essa profissão e a utilização dos conteúdos matemáticos selecionados na mesma. Estes conteúdos foram, então, adaptados à profissão.

A seguir, foi preciso estabelecer os pré-requisitos necessários aos conteúdos que seriam abordados. Chegou-se, então, aos seguintes pontos: medidas de ângulos (usando transferidor); transformações de medidas (comprimento, superfície e volume); medidas (régua, trena etc.); classificação dos triângulos; semelhança de triângulos; escalas e outras proporcionalidades. Foi, então, definido um projeto relativo à profissão selecionada, com ênfase nos conteúdos de trigonometria no triângulo retângulo e de áreas de figuras planas, para a série escolhida.

Outro aspecto necessário foi definir os espaços e locais que seriam utilizados para o trabalho de campo. Detectou-se que a própria estrutura da escola, incluindo sua quadra, e as adjacências, como a praça pública, poderiam ser utilizadas para este fim, já que dispunham de formas geométricas suficientes para trabalhar com as áreas de figuras planas planejadas. Como a praça estava em reforma e não era do conhecimento da comunidade como iria ficar depois de pronta, surgiu, também, uma oportunidade de os alunos explorarem sua criatividade. O projeto ficou definido como: a construção de uma maquete da escola e plantas baixas da escola e da praça, em escala.

\subsection{3ㅁ Etapa - Execução}

Esta fase foi fundamental para que os alunos pudessem vivenciar e construir os conceitos necessários por meio do projeto prático definido. Inicialmente, o professor explicou aos alunos as atividades que seriam realizadas. Esclareceu que a construção de maquetes e plantas baixas deveria respeitar escalas, que necessitariam realizar pesquisas, construir objetos, fazer visita de campo, apresentações, realizar medições e entender os conceitos matemáticos que seriam trabalhados.

Com o intuito de verificar o nível de conhecimento real dos alunos em conceitos básicos, em diversos momentos, o professor pediu que os grupos fizessem pesquisas e apresentassem o resultado. Com as dificuldades observadas, houve a necessidade de novas definições e 
explicações. O professor, então, pôde atuar na Zona de Desenvolvimento Proximal dos alunos, os auxiliando nos conhecimentos ainda não desenvolvidos. Isso foi feito de forma expositiva, no quadro, explicando-se os conceitos pesquisados, para que houvesse um nivelamento da turma para execução do projeto.

\subsubsection{Tarefa 1 - Trabalhando os pré-requisitos}

Primeiramente, o professor pediu para que os alunos fizessem uma pesquisa sobre ângulos, medidas de ângulos e triângulos retângulos e que cada um teria um bloco/caderno de anotações para registrar as pesquisas e dúvidas sobre os pré-requisitos.

$\mathrm{Na}$ aula seguinte, esses assuntos foram discutidos. O professor percebeu que muitos alunos não sabiam medir ângulos nem o que era um transferidor. Outros conheciam o transferidor, mas não sabiam a sua utilidade. Assim, o professor pode conceituar ângulo, explicar como usar o transferidor e relembrar aos alunos outros conteúdos que seriam necessários para o trabalho.

\subsubsection{Tarefa 2 - Pesquisa sobre teodolito artesanal}

Calcular a altura da cobertura da quadra, determinar a altura da escola, a quantidade de piso necessário para revestir o chão e as paredes das salas de aula foram desafios que surgiram com o andamento do trabalho. Para que algumas dessas tarefas fossem executadas, houve a necessidade de utilizar um teodolito, que foi, posteriormente, construído de forma artesanal pelos alunos. Inicialmente, foi pedido aos alunos que fizessem uma pesquisa sobre um teodolito artesanal e materiais necessários para sua construção. Em sala de aula, o professor observou a explicação dos grupos sobre a pesquisa realizada e passou um vídeo sobre a construção de um teodolito artesanal.

Foi observado que os materiais necessários para construção do teodolito eram bem parecidos tanto nas pesquisas feitas pelos alunos, quanto no vídeo exibido pelo professor. $\mathrm{O}$ vídeo foi necessário para que eles fizessem essa comparação e, também, devido aos alunos que não fizeram a pesquisa. Ficou combinado que na aula seguinte os grupos trariam copos ou potes plásticos descartáveis, canudo, um pedaço de madeira ou papelão e arame, pois a escola não tinha esses objetos, mas eles eram facilmente obtidos, sem a necessidade de gasto financeiro. 


\subsubsection{Tarefa 3 - Construção de um teodolito artesanal}

A tarefa dos alunos aqui era efetivamente construir um teodolito artesanal, com os materiais solicitados anteriormente, o que foi realizado em três aulas. Houve alguns problemas, como o esquecimento dos objetos por alguns alunos e dificuldade de outros para entender o que era para ser feito, especialmente os que faltaram à aula anterior. Assim, o professor pediu que os grupos se reunissem em partes diferentes da sala de aula e que os que estivessem com o material completo começassem a construção do teodolito, solicitando ajuda do professor ou de algum colega, em caso de dúvidas. Enquanto isso, o professor reafirmava o compromisso com os grupos que esqueceram os materiais e explicava a tarefa para os alunos que haviam faltado ou não haviam compreendido. A Figura 2 mostra os alunos construindo o teodolito artesanal em sala de aula.

Figura 2. Construção do teodolito artesanal pelos alunos.
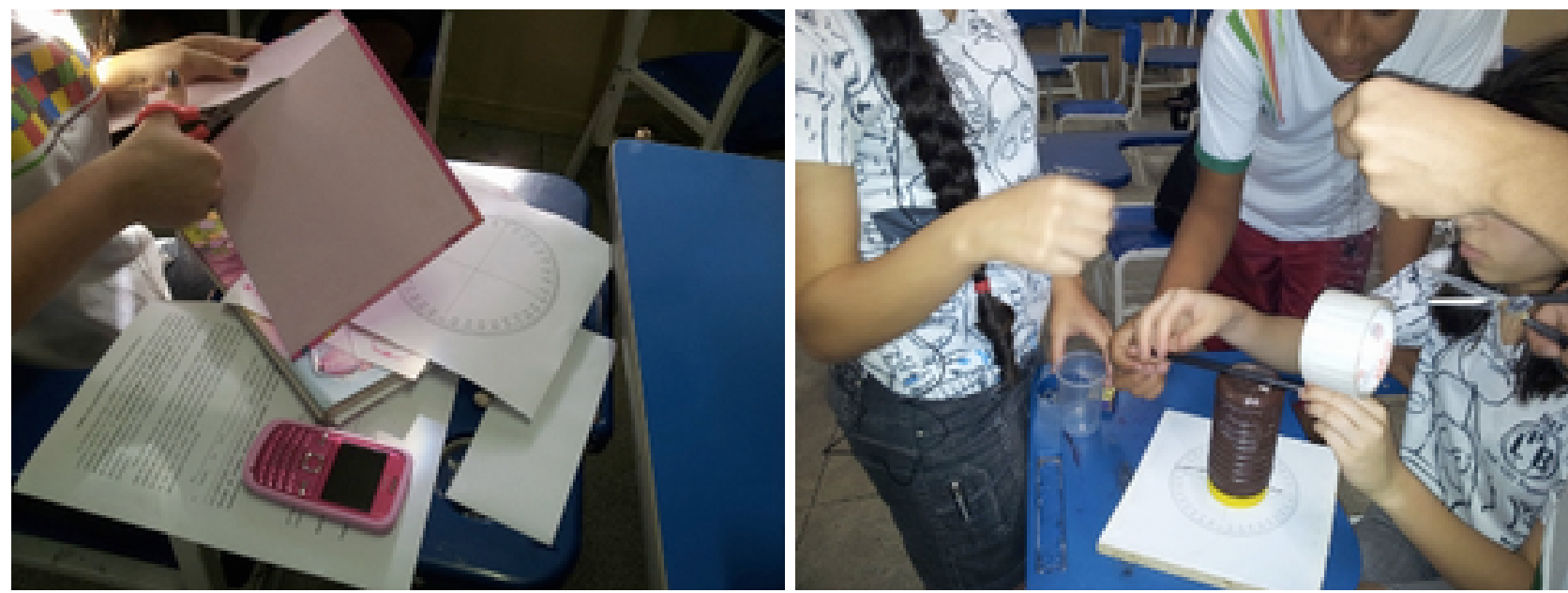

Fonte: O autor, na escola (2012).

\subsubsection{Tarefa 4 - Praticando o uso do teodolito}

Após o teodolito ter sido construído, o professor, em sala de aula, explicou como usá-lo e as medidas importantes a serem registradas. Em seguida, pediu para os alunos treinarem medidas com o teodolito construído por eles nas dependências da escola. O professor observou e corrigiu os erros cometidos pelos alunos: Não posicionar o ponteiro no ângulo de zero grau, no início da medida; retirar o teodolito da posição após medir o ângulo, sem determinar a distancia até o objeto medido para relacioná-lo com o ângulo; não medir a altura do teodolito ao chão. Para a próxima tarefa, seria necessário o teodolito e uma trena (ou outro objeto de medida), para determinação das medidas oficiais que seriam usadas na elaboração do trabalho. 


\subsubsection{Tarefa 5 - Medições}

As aulas da semana seguinte foram para realização das medidas oficiais que os grupos usariam em seus projetos. Eles mediram os espaços físicos da escola, utilizando o teodolito artesanal construído por eles e a trena, como mostram, respectivamente, as fotos da Figura 3.

Figura 3. Alunos realizando medições.
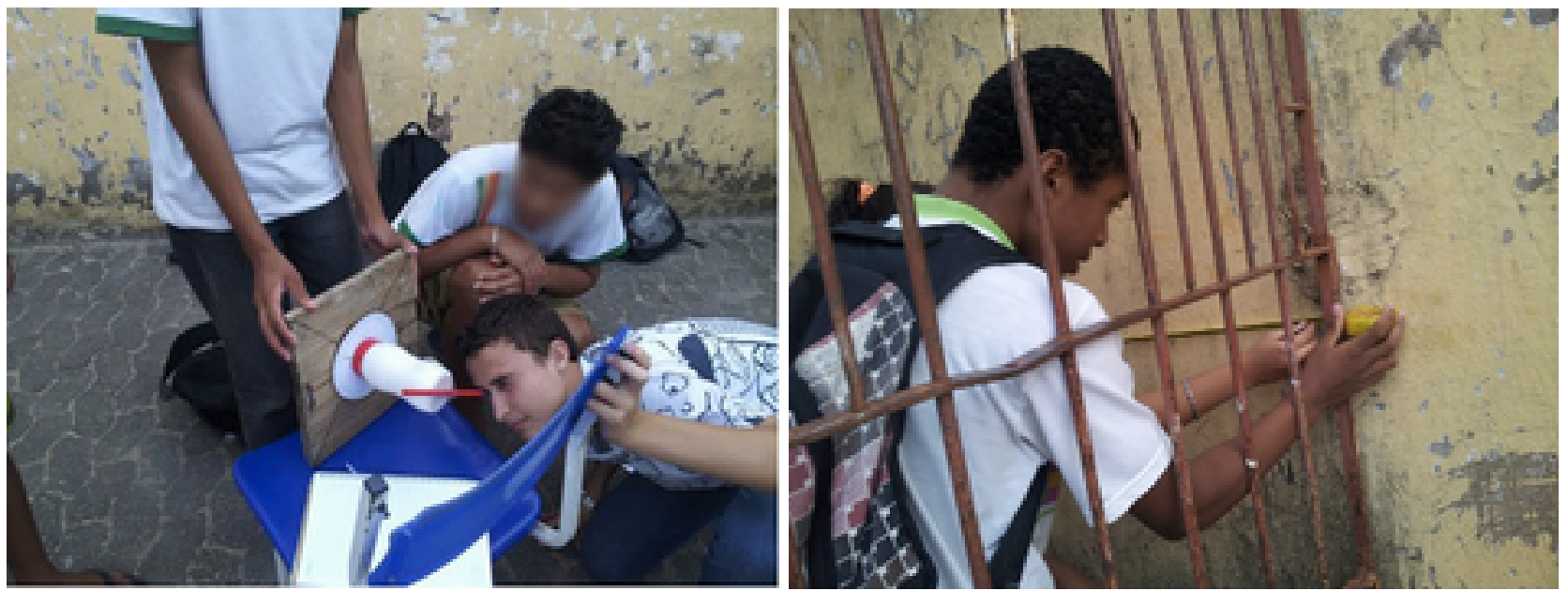

Fonte: O autor, na escola (2012).

Durante as medições, foi observado que os alunos apresentaram dificuldades em conceitos que o professor julgava que eles já conheciam. Alguns grupos, por exemplo, tiveram problemas para determinar medidas longas e, quando as determinavam, cometiam erros exagerados. O professor notou que esses grupos faziam essas medidas usando partes não inteiras do metro, como por exemplo, $2,67 \mathrm{~m}$ ou $3,56 \mathrm{~m}$ ao invés de $3 \mathrm{~m}, 4 \mathrm{~m}$ ou $5 \mathrm{~m}$. O professor interveio para explicar que a forma usada por eles não era errada, porém era mais trabalhosa para somar, podendo, assim, aumentar a possibilidade de erro no resultado final, que foi justamente o que ocorreu com alguns grupos. Devido ao tamanho da trena que eles utilizavam, foi sugerido, então, que medissem de 5 em 5 metros. Dessa forma, as medidas longas seriam o resultado de somas de partes de $5 \mathrm{~m}$ e da última, que poderia não ser múltipla do metro. Isso facilitaria calcular o comprimento total da medida. 
Outro problema detectado foi que alguns grupos estavam com dificuldades para trabalhar com números decimais. Por exemplo, quando a trena marcava $3,01 \mathrm{~m}$ eles anotavam $3,1 \mathrm{~m}$ cometendo um erro de $9 \mathrm{~cm}$. O professor interveio para explicar o erro que estava sendo cometido. Também foram encontrados erros, quando o local a ser medido tinha um obstáculo, como um muro que estava em parte sendo bloqueado por uma grade, como mostra a segunda foto da Figura 3 . Foi sugerido que primeiro medissem o lado que era possível, depois dessem a volta para o outro lado, para medir a parte que faltava e, posteriormente, somassem as duas partes.

Uma dificuldade também foi notada quando os alunos tentavam medir uma parede com muitas colunas que eram mais externas que ela. Alguns grupos julgaram, sem conferir, que essas colunas estavam igualmente espaçadas e, com isso, concluíram que bastava medir uma parte da parede entre essas colunas e multiplicar pelo total de partes da parede. Além disso, eles não perceberam a necessidade de medir também as colunas e adicionar ao somatório total.

Nesta mesma parede, outros grupos estavam medindo de uma coluna a outra deixando a trena formar "barriga". O professor explicou que isso geraria medidas incorretas e sugeriu que medissem pela calçada, que era encostada na parede e tinha a borda paralela à mesma. Alguns grupos, por outro lado, já tinha notando esse paralelismo para fazer esta medida.

Todos tiveram a oportunidade de medir ângulos e relacioná-los com o triângulo retângulo, o que gerou a necessidade de novos conhecimentos como: seno, cosseno e tangente. Durante as medições, outras dificuldades ocorreram, levando à necessidade de buscar, também, conhecimentos relativos à geometria plana, como a determinação de áreas a partir das medidas obtidas e das figuras geométricas que eles iriam utilizar na construção da planta baixa.

\subsubsection{Tarefa 6 - Descobrindo a trigonometria no triângulo retângulo}

Durante as medições, muitos alunos perguntavam: "Como eu posso achar a altura tendo só essas medidas?". Ao invés de respondê-la de forma direta, o professor aproveitou essa pergunta e a reformulou da seguinte forma: "Conhecendo um ângulo e um lado do triângulo retângulo, como calcular os outros dois lados do triângulo"? De posse dessa pergunta, os alunos foram levados ao laboratório de informática para procurar uma possível resposta. 
Os conteúdos encontrados pelos alunos foram sobre: relações métricas no triângulo retângulo e Trigonometria. Para os que encontraram relações métricas, o professor pediu para eles observarem se as fórmulas estavam relacionando ângulo com lado e esperou que os próprios alunos percebessem que não e encontrassem o conteúdo pretendido, que era o de Trigonometria.

Após verificar que todos os grupos estavam no caminho pretendido e ter constatado que os alunos tinham acesso à internet fora da escola, o professor pediu que eles enviassem por e-mail a todos os componentes de seus respectivos grupos, as fontes encontradas na pesquisa (textos ou vídeos). Assim, poderiam continuar a pesquisa em casa, uma vez que, nas próximas duas aulas, os grupos iriam se reunir para elaborar apresentações do que haviam entendido ou aprendido.

O professor queria identificar nas apresentações qual o conhecimento real de cada aluno, para desenvolver estratégias para atuar na Zona de Desenvolvimento Proximal (ZDP) e, com isso, poder maximizar a transformação de conhecimento potencial em conhecimento real. Todos cumpriram a atividade e os resultados obtidos nas apresentações foram considerados muito satisfatórios, já que os conteúdos aprendidos pelos alunos atingiram em grande proporção o que as turmas anteriores conseguiam aprender apenas após as aulas expositivas.

O professor pôde observar os seguintes resultados: grande parte dos alunos conseguia identificar triângulo retângulo e classificar seus lados em relação a um dos seus ângulos agudos; os alunos sabiam da existência das fórmulas seno, cosseno e tangente e alguns já faziam cálculos simples, utilizando estas fórmulas, com facilidade; todos apresentaram, inclusive os mais tímidos, e mostravam o que haviam entendido e o que não conseguiram compreender; o entrosamento entre os colegas foi de solidariedade e aprendizado; os alunos descobriram que havia uma tabela que indicava o seno, o cosseno e tangente de ângulos inteiros de 1 a 90 graus; a maioria dos alunos, por conta própria, fez uso constantemente do livro didático, o que é considerado um fator positivo, pois em grande parte do ano, muitos não traziam seus livros e muito menos faziam as atividades. 
Apesar de ter considerado a participação dos alunos positiva, o aprendizado não é o mesmo para todos, assim o professor julgou necessário finalizar esta etapa com uma explicação expositiva sobre os conteúdos trabalhados, para consolidar os conhecimentos adquiridos, o que foi feito nas aulas seguintes, inclusive com a realização e correção de exercícios. Na semana seguinte, o professor reforçou como seriam as construções da maquete e das plantas baixa e, também, trabalhou problemas envolvendo trigonometria, usando o livro didático.

\subsubsection{Tarefa 7 - Descobrindo áreas de Figuras Planas}

Assim como na Trigonometria do triângulo retângulo, o conhecimento sobre área de figuras planas foi construído por meio de pesquisas, apresentações e perguntas feitas pelos alunos durante as medições ou em sala de aula, por meio de aulas expositivas. Incialmente lidaram com temas mais simples, como área e perímetro de triângulo e retângulo (incluindo o quadrado) e, posteriormente, trabalharam outros conteúdos geométricos como: paralelogramo, trapézio, losango, pentágono, hexágono regular, círculos (circunferência), coroa circular, setor circular etc. Em seguida, os grupos tiveram oportunidades de continuar medindo a escola e colocar em prática os aprendizados recentes. As dificuldades em resolver problemas e determinar áreas de figuras sombreadas com polígonos ou círculos inscritos ou internos permaneceram em algumas situações, porém em menor escala que nas turmas anteriores.

\subsubsection{Tarefa 8 - Visita ao canteiro de obra}

A visita foi realizada em um canteiro de obra de uma construção de grande porte, devido ao fato de ela possuir, naquele momento, diferentes estágios de desenvolvimento. Os alunos tiveram a oportunidade de tirar dúvidas com engenheiros e técnicos de segurança do trabalho. Uma dúvida frequente era sobre a construção de rampas de acessibilidade. Foi explicado pelo engenheiro que, para construção de rampas, deve-se haver uma proporção entre a altura e o comprimento da base de no máximo $8 \%$, ou seja, a cada $1 \mathrm{~m}$ da base a elevação deverá ser no máximo de $8 \mathrm{~cm}$. Assim, os alunos entenderam porque a rampa da escola é tão comprida. Outra dúvida comum era como representar na planta baixa os andares acima do primeiro. O engenheiro explicou como fazer essa representação, mostrando a planta de um prédio que estava em construção e também falou sobre a escala de medida usada na planta. Os técnicos de segurança do trabalho explicaram aos alunos sobre os materiais utilizados na obra, os testes feitos com os mesmos para verificação da 
qualidade e sobre a segurança que os funcionários da obra devem ter durante o trabalho. 


\subsubsection{Tarefa 9 - Construção das maquetes e plantas baixas}

Devido ao tamanho e uso de materiais frágeis como isopor, papelão, cartolinas etc, as maquetes e as plantas baixas foram construídas na casa dos alunos. O acompanhamento era feito pelo professor através de fotos (como na Figura 4) ou citações dos alunos durante as aulas.

Figura 4. Construção das maquetes nas casas dos alunos.
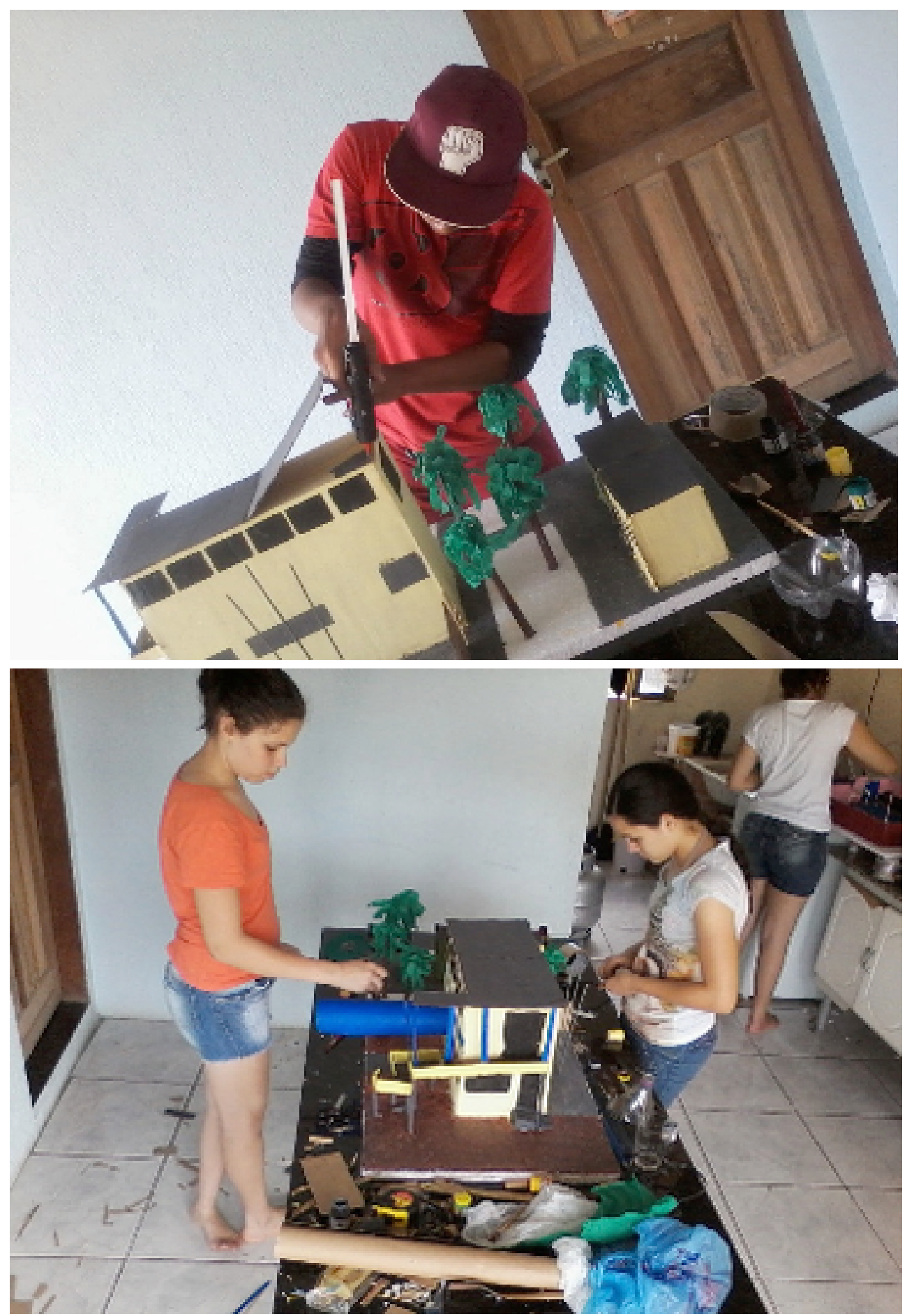
Fonte: Alunos (2012).

Surgiram dúvidas em relação à conversão para escala pedida (podia ser $1 \mathrm{~m} / 1 \mathrm{~cm}$ ou $1 \mathrm{~m} / 2 \mathrm{~cm}$ ) e de como fazer a rampa de acessibilidade que a escola possui. Parte dessas dúvidas foi sanada pelo engenheiro da construtora, como citado anteriormente. Porém, o professor, também, deu aulas expositivas para complementar o aprendizado.

Para que os alunos não utilizassem em seus trabalhos apenas formas geométricas mais simples, 0 que limitaria seu aprendizado, e sabendo-se que a praça estava em reforma, o professor mostrou várias formas geométricas e pediu que os grupos criassem uma planta baixa de como queriam que ela ficasse depois de pronta, usando todas essas formas geométricas e também outras que poderiam ser criadas pelo próprio grupo. Essas formas poderiam representar um brinquedo, um palco, um jardim, etc. Cada grupo deveria usar sua criatividade e desenhar a praça desejada, respeitando as medidas e a escala, pois o cálculo das áreas de cada figura seria observado, inclusive a área restante da praça que não havia sido ocupada, para certificar se a forma com que cada grupo construiu a planta baixa era coerente com as medidas e a escala. Essas tarefas (construção de maquete e plantas baixas) levaram aproximadamente um mês e meio para serem executadas, pois em paralelo a elas os alunos tinham também tarefas em sala de aula, pesquisas, apresentações e prova, além das atividades de outras disciplinas.

\subsubsection{Avaliação dos alunos}

Visando a obter uma comparação mais realista entre turmas passadas e as atuais, as avaliações e a distribuição dos pontos aqui adotados procuraram se aproximar do que já havia sido feito até então, inclusive, referente ao grau de dificuldade das provas. Porém, como ocorreram algumas mudanças na escola, passando do sistema de bimestre para trimestre, houve alterações nos valores totais das atividades. Dessa forma, os valores serão expostos neste trabalho na forma de percentuais.

Em todos os anos, os alunos foram avaliados por meio de provas ( $40 \%$ da nota), trabalhos ( $40 \%$ da nota) e participação e atitudes ( $20 \%$ da nota).

As normas da secretaria da educação da Serra (SEDU) estabelecem que alunos com notas abaixo de $60 \%$ do valor total devem ter outra oportunidade, por meio de uma recuperação paralela. No caso das provas referentes aos conteúdos abordados neste projeto, para as turmas de 2007 a 
2011, foram aplicadas duas provas, uma com o conteúdo de trigonometria no triângulo retângulo e a outra com áreas de figuras planas, e as duas respectivas provas de recuperação paralela, prevalecendo a nota maior entre a primeira prova e a de recuperação paralela. Para as turmas de 2012, objeto de estudo do presente trabalho, foram aplicadas também duas provas, uma para cada conteúdo, porém apenas uma prova de recuperação paralela, com os dois conteúdos abordados, prevalecendo a maior nota entre a soma das duas primeiras e nota da prova de recuperação.

\subsubsection{Apresentação final dos trabalhos}

Os trabalhos construídos foram expostos e apresentados para os alunos e funcionários da escola (Figura 5). Os alunos expositores no inicio ficaram meio tímidos, mas depois conseguiram fazer as apresentações. Para os visitantes, o que chamava mais atenção no primeiro momento eram as maquetes expostas e a quantidade de recursos utilizados. Só notavam a Matemática que existia ali por trás quando ouviam as explicações dos alunos expositores.

Pelas explicações aos visitantes, era possível observar que os alunos expositores estavam entendendo a utilização da matemática através dos materiais concretos por eles construídos.

Tendo em conta todas as situações enfrentadas diariamente por esses alunos na comunidade em que vivem, as deficiências de conteúdos e as dificuldades de aprendizagem, defendemos que os resultados de seus trabalhos apresentados nessa exposição conseguiram não apenas cumprir, mas superar o que era esperado inicialmente.

Figura 5. Exposição e apresentação dos trabalhos finais dos alunos
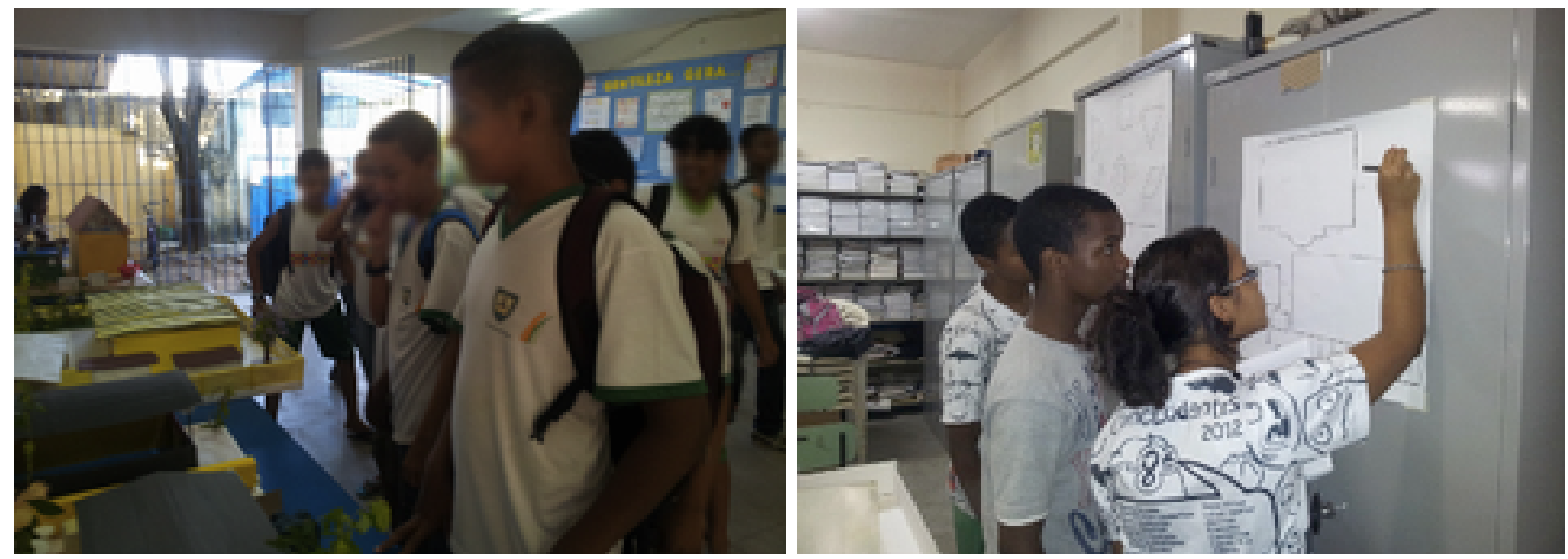

Fonte: O autor, na escola (2012). 


\subsection{4a Etapa - Análise}

Nesta etapa, foram analisadas as produções dos alunos e o que foi coletado pelo professor, como falas e atitudes dos alunos, registrados durante a execução do projeto, por meio de fotos, vídeos e anotações, assim como os relatórios produzidos por eles.

As avaliações dos alunos também foram analisadas, o que tornou possível realizar algumas comparações com os resultados das turmas anteriores (que tiveram o mesmo professor do presente projeto), respeitando-se suas particularidades, uma vez que se trata de pessoas diferentes, com situação socioeconômica distintas, que chegam àquela série com diferentes níveis de conhecimento.

O questionário que eles preencheram ao final do projeto também foi de suma importância para identificar o como eles compreendiam antes a Matemática e como a vêm na atualidade, e o quanto o projeto contribuiu para o aprendizado, em suas visões.

Enfim, nas análises realizadas aqui se objetivou observar se esta abordagem de trabalho contribuiu para o aprendizado dos alunos e conseguiu superar as dificuldades encontradas.

\subsubsection{Análises das avaliações dos alunos}

A Tabela 1 mostra as médias dos alunos nos conteúdos trabalhados no presente projeto, referentes às turmas de 2007 a 2012, considerando-se o resultado das provas, trabalhos e participação e comportamento. A turma 2012, objeto de estudo deste trabalho, encontra-se destacada. Vale lembrar que o seu resultado é exibido consolidado devido à forma como foi realizada a recuperação paralela nas provas (uma única para os dois conteúdos).

Tabela 1. Médias dos alunos nos conteúdos deste projeto, nos anos 2007 a 2012.

\begin{tabular}{|l|c|c|c|c|c|c|}
\hline \multicolumn{1}{|c|}{ Ano } & 2007 & 2008 & 2009 & 2010 & 2011 & 2012 \\
\hline $\begin{array}{l}\text { Trigonometria no triângulo } \\
\text { retângulo }\end{array}$ & $39 \%$ & $41 \%$ & $44 \%$ & $46 \%$ & $57 \%$ & $75 \%$ \\
\hline Áreas de figuras planas & $63 \%$ & $64 \%$ & $73 \%$ & $60 \%$ & $63 \%$ & $75 \%$ \\
\hline $\begin{array}{l}\text { Média aritmética dos dois } \\
\text { conteúdos acima }\end{array}$ & $51 \%$ & $52 \%$ & $58 \%$ & $53 \%$ & $60 \%$ & 7 \\
\hline
\end{tabular}

Fonte: 0 autor (2012).

O Gráfico 4 mostra a variação das médias dos alunos entre os anos 2007 e 2012. 
Gráfico 4. Variação das médias entre os anos 2007 a 2012

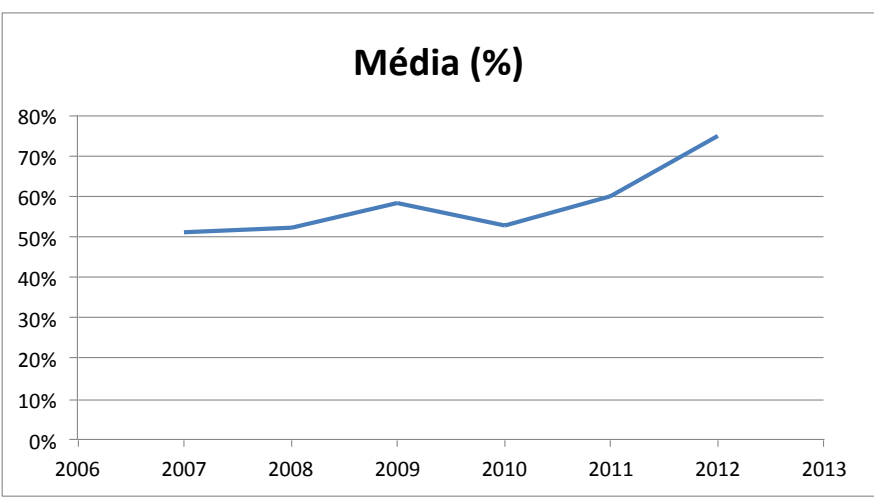

Fonte: 0 autor (2012).

Como podemos observar na Tabela 1 e no Gráfico 4, houve melhoria considerável nas médias dos alunos nas turmas 2012, o que, por si só, já evidencia um resultado positivo deste projeto. Como cita Markhan e outros (2008, p. 20), a aprendizagem baseada em projetos "envolve e motiva alunos entediados ou indiferentes".

Podemos deduzir, então, que o projeto motivou os alunos, contribuindo para que se tornassem mais participativos e engajados e, assim, eles obtiveram notas melhores no trabalho e em participação/comportamento. Mas será que essa melhoria se reflete, também, nas notas das provas?

A Tabela 2 mostra um comparativo entre a média obtida em prova e a média obtida pelas outras avaliações (trabalho e participação/comportamento/atitude), referentes às turmas de 2007 a 2012.

Podemos notar que o desempenho dos alunos nas provas foi pior que nas outras avaliações em todos os anos, pelo fato de grande parte dos alunos não gostar de fazer prova, por ser uma atividade individual, sem consulta e em um tempo determinado e pelo nervosismo comum a muitos.

Percebemos, porém, que nas turmas de 2012, objeto de estudo deste projeto, os resultados dos alunos nas provas melhoraram significativamente, tendo estes, de forma geral, ficado acima da média (62\%), mesmo que considerando apenas esse tipo de avaliação. Ou seja, 
podemos perceber que este projeto ajudou os alunos tanto a desenvolver competências para realização do trabalho em grupo, para as apresentações e na participação/comportamento, como também ajudou efetivamente a melhorar o desempenho nas provas.

Tabela 2. Comparativo entre as notas em provas e em outras avaliações de 2007 a 2012.

\begin{tabular}{|c|c|c|c|}
\hline Ano & $\begin{array}{c}\text { Média da Turma em } \\
\text { Prova (\%) }\end{array}$ & $\begin{array}{c}\text { Média da Turma em outras } \\
\text { avaliações }\end{array}$ & $\begin{array}{c}\text { Média da Turma } \\
\text { (\%) }\end{array}$ \\
\hline 2007 & $47 \%$ & $55 \%$ & $51 \%$ \\
\hline 2008 & $43 \%$ & $61 \%$ & $52 \%$ \\
\hline 2009 & $35 \%$ & $81 \%$ & $58 \%$ \\
\hline 2010 & $52 \%$ & $54 \%$ & $53 \%$ \\
\hline 2011 & $51 \%$ & $69 \%$ & $75 \%$ \\
\hline 2012 & $62 \%$ & $88 \%$ & \\
\hline
\end{tabular}

Fonte: 0 autor (2012).

Mas sabe-se, também, que cada turma tem alunos com perfis diferentes. Sendo assim, não poderia ser considerado simplesmente que essas turmas de 2012 poderiam ser melhores que as turmas dos anos anteriores? Com base nessa inquietação, foi elaborado um comparativo das médias de provas da disciplina de Matemática, entre os trimestres das turmas de 2012, que constam na Tabela 3. 0 presente projeto foi realizado no $3^{\circ}$ trimestre.

Tabela 3. Comparativo entre as notas em provas e em outras avaliações de 2007 a 2012.

\begin{tabular}{|c|c|c|c|}
\hline Ano & $\begin{array}{c}\text { Média Prova 1 } \\
\text { trimestre (\%) }\end{array}$ & $\begin{array}{c}\text { Média Prova 2 } \\
\text { trimestre (\%) }\end{array}$ & $\begin{array}{c}\text { Média Prova 3 } \\
\text { trimestre (\%) }\end{array}$ \\
\hline 2012 & $35 \%$ & $44 \%$ & $62 \%$ \\
\hline
\end{tabular}

Fonte: 0 autor (2012).

Como se pode observar, os resultados obtidos nos dois primeiros trimestres apontavam que muitos alunos possivelmente ficariam em recuperação ou reprovados. Contudo, com a implantação do projeto, muitos alunos conseguiram resgatar a motivação, passaram a se empenhar mais e, com isto, melhoraram o desempenho nas provas e em todas as outras avaliações (inclusive em outras disciplinas). Isso acarretou, ainda, a redução do índice de 
reprovação, que nas turmas anteriores estava em torno de 33\% e nas turmas 2012 ficou próximo a $10 \%$.

\subsubsection{Análises da avaliação do projeto pelos alunos}

Os alunos tiveram oportunidades de avaliar o projeto através de um questionário e de um relatório. A seguir faremos uma breve análise sobre suas respostas no questionário e, também, de algumas falas oriundas dos relatórios.

O Gráfico 5 mostra o interesse e facilidade dos alunos pela disciplina de matemática. Dois dados chamam mais a atenção: o fato de nenhum aluno se encaixar na opção "Não gosto e tenho dificuldade de aprender" e o alto índice de alunos (72\%) na opção "Gosto, mas tenho dificuldade de aprender". Isso parece indicar que existia muito mais uma dificuldade de compreensão dos seus conteúdos do que uma rejeição pela mesma, como se poderia a princípio imaginar. Pode indicar, também, que o projeto contribuiu para que essa rejeição diminuísse.

\section{Gráfico 5. Interesse e facilidade pela disciplina de Matemática}

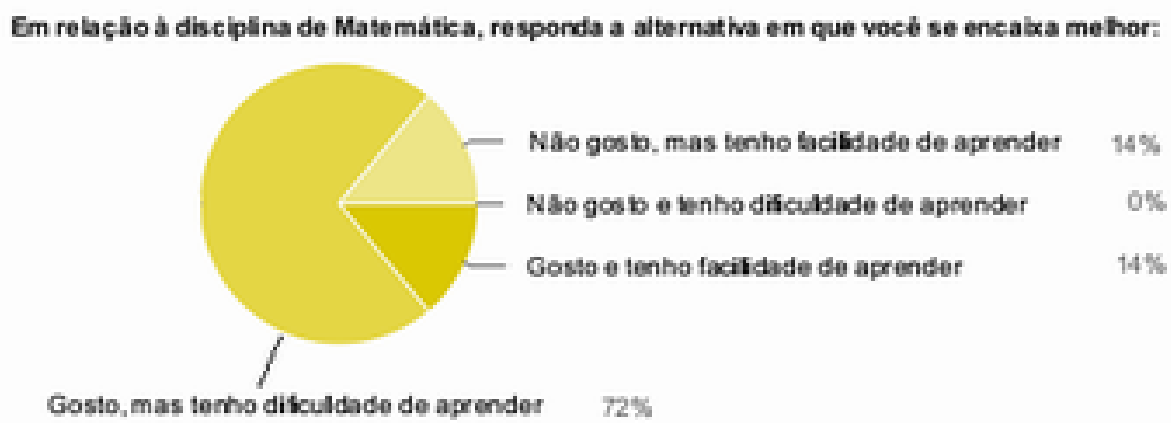

Fonte: 0 autor (2012).

Os depoimentos abaixo, retirados dos relatórios dos alunos (inclusive dos que reprovaram nesta mesma série no ano anterior), deixam evidente sua satisfação em aprender. Isso mostra que o aluno tem interesse, porém este muitas vezes é encoberto pela baixa autoestima gerada por fracassos de conteúdos anteriores. 
"Eu aprendi coisas de que eu não sabia a Trigonometria e áreas de figuras planas que era um bicho de sete cabeças para mim."

"Eu aprendi muito com o trabalho de Matemática, apesar da dificuldade muito grande na matéria."

"Nesse trabalho eu conseguir aprender muito mais da Matemática, do que no ano passado."

O Gráfico 6 mostra a opinião dos alunos em relação à importância do aprendizado da Matemática. Podemos perceber que, ao final do projeto, 92\% considerava que aprender Matemática era importante, o que é um dado muito significativo, uma vez que em turmas anteriores era grande a quantidade de alunos que não percebia a importância e utilidade prática da Matemática. A participação em um projeto prático, que pode mostrar a aplicação da Matemática em situações concretas, certamente contribuiu para esse resultado. Como cita Markhan e outros (2008, p. 20), a aprendizagem baseada em projetos: "supera a dicotomia entre conhecimento e pensamento, ajudando os alunos a 'saber' e 'fazer'".

\section{Gráfico 6. Importância da Matemática para os alunos}
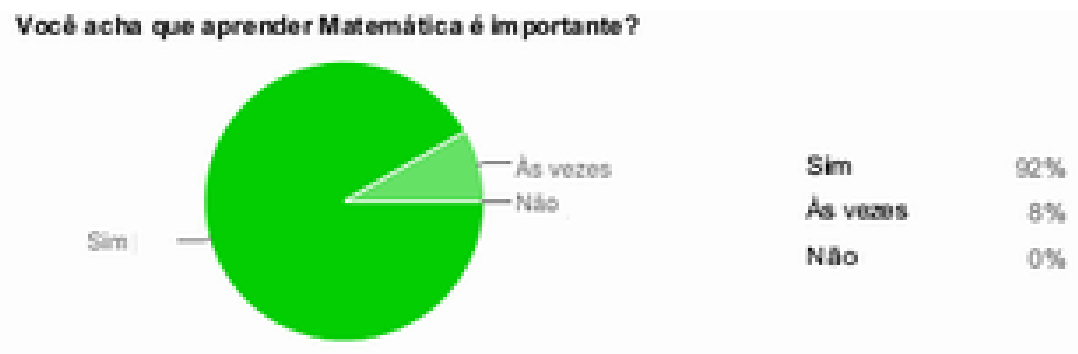

Fonte: 0 autor (2012).

O Gráfico 7 mostra a opinião dos alunos sobre as atividades ocorridas durante a execução do projeto. Podemos notar que $97 \%$ dos alunos optaram por pelo menos uma das atividades e que $75 \%$ gosta de fazer trabalhos em grupo, o que ficou visível para o professor durante as apresentações e execuções das atividades feitas na escola. Podemos perceber que as atividades extraclasse também são bem vistas pelos alunos como: visitas técnicas, realização de medições e construção de maquetes. Essas relações forem sempre muito citadas por Freire: "O homem, ser de relações, e não só de contatos, não apenas está no mundo, mas com o mundo" (FREIRE, 1987, p. 111). 
Outra observação importante é o comparativo entre a construção da maquete ( $58 \%$ gostaram) e a construção da planta baixa (31\% gostaram). Se considerarmos que a construção da maquete é mais trabalhosa que a construção da planta baixa, era de se esperar que os alunos gostassem mais da segunda atividade, porém devemos lembrar que os alunos, no início do projeto, fizeram uma exposição onde tiveram a oportunidade de construir maquetes. Ou seja, quando iniciou a execução do projeto, os alunos já tinham certa prática nesta atividade, enquanto a construção de plantas baixa era novidade. $O$ que pode mostrar que os alunos tendem a rejeitar não o que é mais difícil, mas o que é novo. E, também, que eles passam a querer realizar mais as atividades que já foram realizadas anteriormente com sucesso, o que Ihes despertou interesse e curiosidade, o caso das maquetes. Como cita Piaget,

O interesse é o prolongamento das necessidades. É a relação entre um objeto e uma necessidade, pois um objeto torna-se interessante na medida em que corresponde a uma necessidade. Assim sendo, o interesse é a orientação própria a todo ato de assimilação mental (PIAGET, 1993, p. 38).

Gráfico 7. Atividades que os alunos mais gostaram no projeto

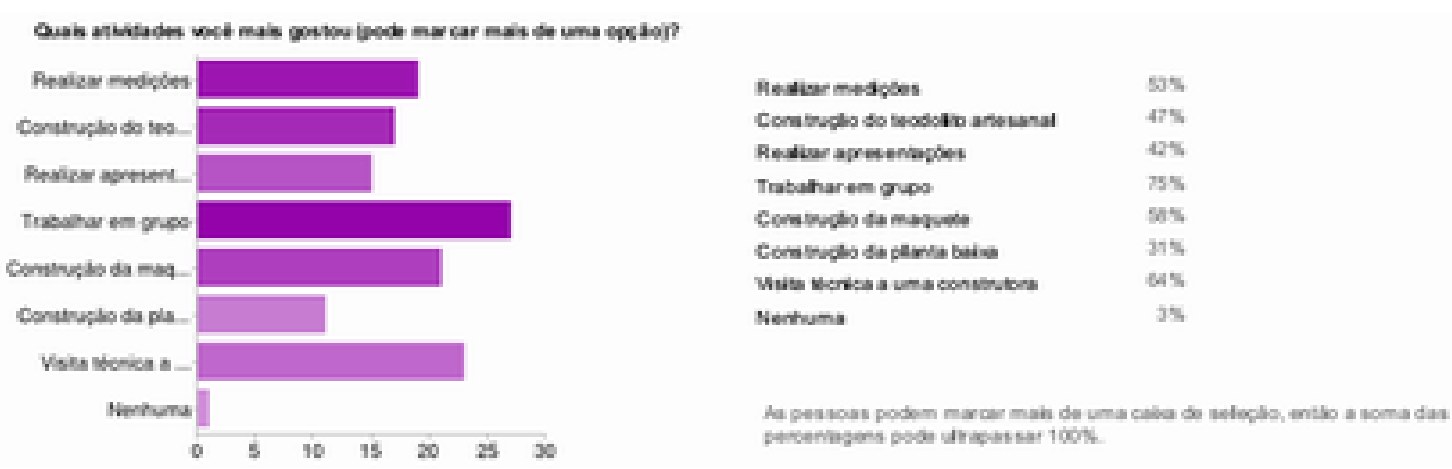

Fonte: 0 autor (2012). 
O Gráfico 8 mostra as atividades em que os alunos sentiram mais dificuldades. Podemos perceber que, mesmo estando entre as atividades que alunos mais gostaram, a construção de maquetes também aparece como a segunda atividade onde os alunos sentiram mais dificuldades (22\%), atrás apenas da construção da planta baixa (25\%). A atividade em grupo, que foi considerada a que os alunos mais gostaram no projeto, foi, por outro lado, considerada por eles um dos maiores itens de dificuldade (19\%). Contudo, apesar de $92 \%$ ter sentido algum tipo de dificuldade, nenhum dos itens apresentou um percentual de dificuldade muito elevado.

\section{Gráfico 8. Atividades em que os alunos tiveram mais dificuldades}

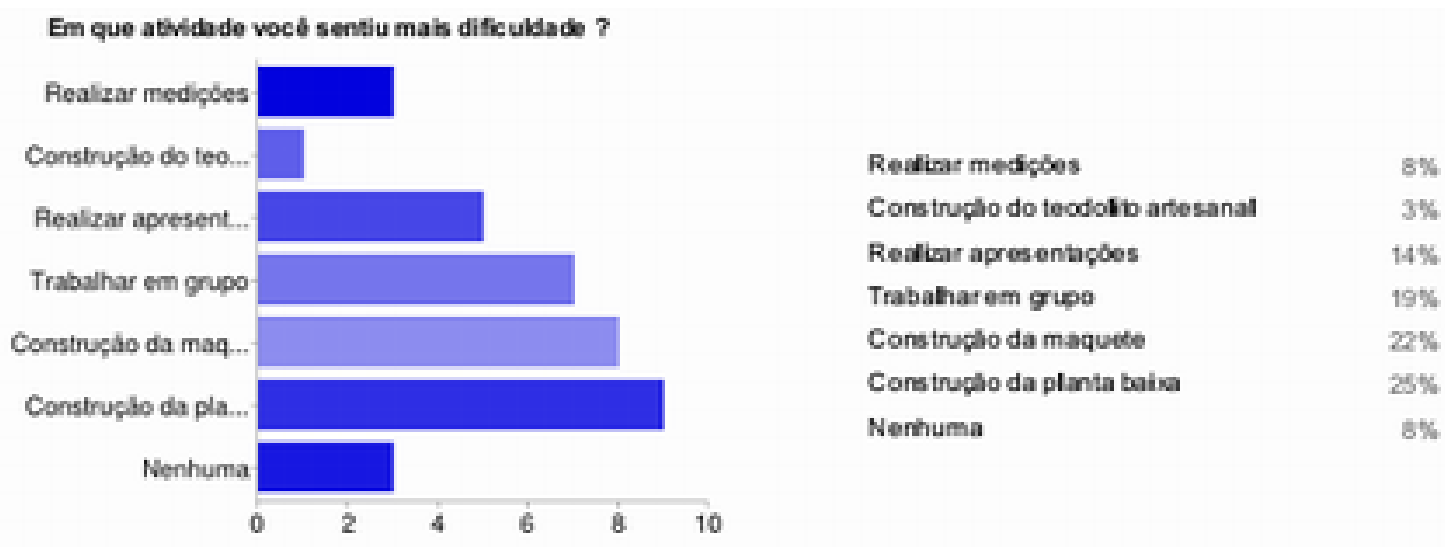

Fonte: 0 autor (2012).

O Gráfico 9 mostra que $92 \%$ dos alunos buscaram alguma alternativa para sanarem suas dúvidas nos momentos em que tiveram dificuldades, especialmente o professor (42\%). Porém, $25 \%$ citaram que nem sempre tiveram sucesso. Os momentos em que os alunos recorriam ao professor ou a outros colegas eram extremamente valiosos para seu aprendizado, uma vez que estes atuavam como mediadores em sua zona de desenvolvimento proximal.

\section{Gráfico 9. Ações dos alunos nos momentos de dificuldades}

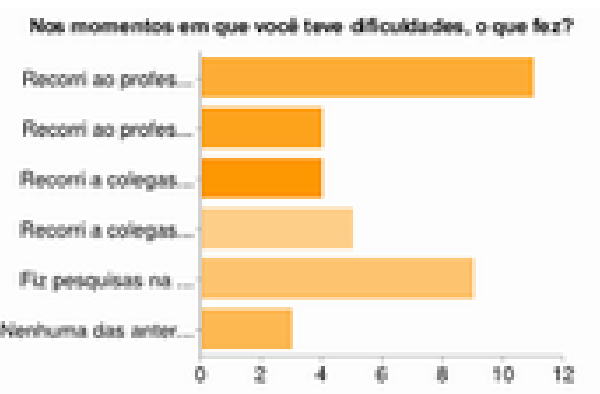

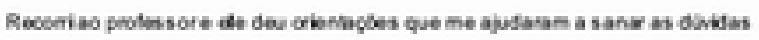

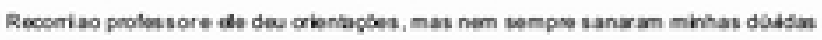

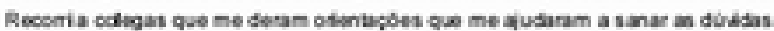

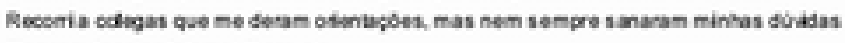
Fepesquhas na intemet thros etc. Nerhuma das ankisores 


\section{Fonte: 0 autor (2012).}

O Gráfico 10 mostra os aprendizados em trigonometria no triângulo retângulo. Observa-se que a maioria dos alunos teve facilidade em lidar com a tabela trigonométrica (88\%) e identificar os lados de um triângulo, dado um dos ângulos agudos internos (72\%). Nos itens de determinação dos ângulos conhecendo dois lados do triângulo retângulo e medição de ângulo com transferidor, mais da metade dos alunos sentiram dificuldades, o que foi surpresa para o professor, pois essas dificuldades não transpareceram muito durante as aulas. E um terço dos alunos citou que tem dificuldades de montar e resolver problemas, o que é uma característica frequentemente encontrada nos alunos desta e de outras escolas, não apenas em Matemática, mas em interpretação de textos de forma geral, o que pode ser visto nos resultados negativos do Brasil nas avaliações do PISA. Porém, se comparado a turmas anteriores, houve uma melhoria significativa. Nos outros itens temos uma avaliação em torno de $70 \%$, que está bem próximo da média da turma (75\%), como exibido anteriormente.

\section{Gráfico 10. Aprendizados em trigonometria no triângulo retângulo}
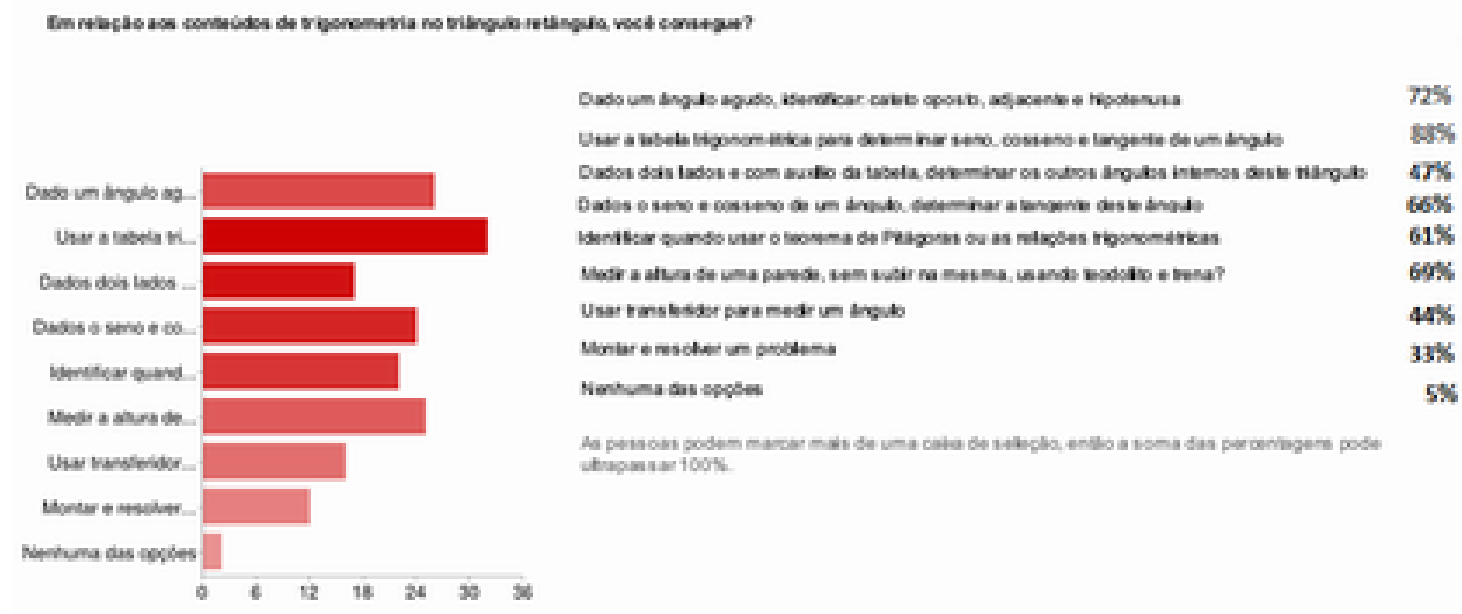

Fonte: 0 autor (2012).

O Gráfico 11 mostra que, para os alunos, o conteúdo sobre áreas de figuras planas foi compreendido em quase sua totalidade. Porém, há dificuldades, ainda, em calcular áreas sombreadas e resolver e montar problemas. Entretanto, como também citado com relação à Trigonometria, houve avanços significativos nesses dois quesitos em comparação com turmas anteriores, em que os resultados estavam abaixo da metade desses índices. 


\section{Gráfico 11. Aprendizados em áreas de figuras planas}

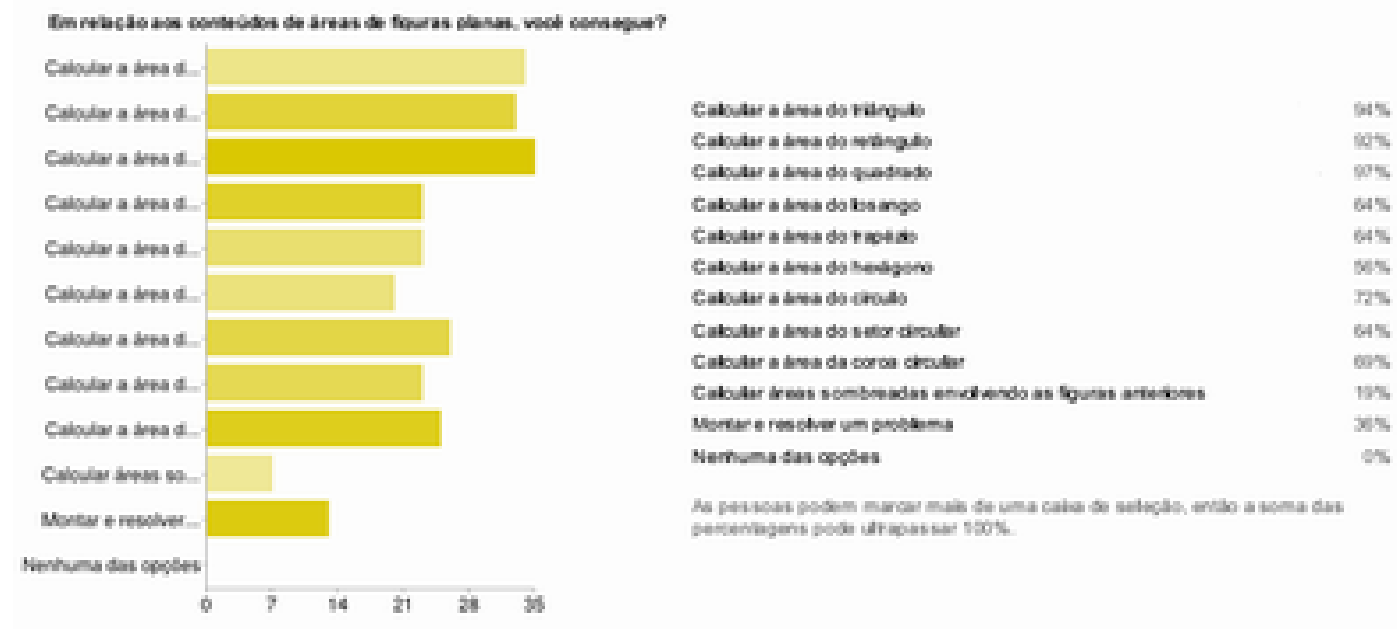

Fonte: $O$ autor (2012).

No Gráfico 12, podemos perceber que a grande maioria dos alunos (94\%) considera que o projeto facilitou o aprendizado; possibilitou a percepção da aplicabilidade e um olhar positivo da matemática por parte dos alunos e abriu espaço para relação entre aluno/professor e aluno/ aluno.

\section{Gráfico 12. Contribuições do estudo de matemática por meio de projetos}

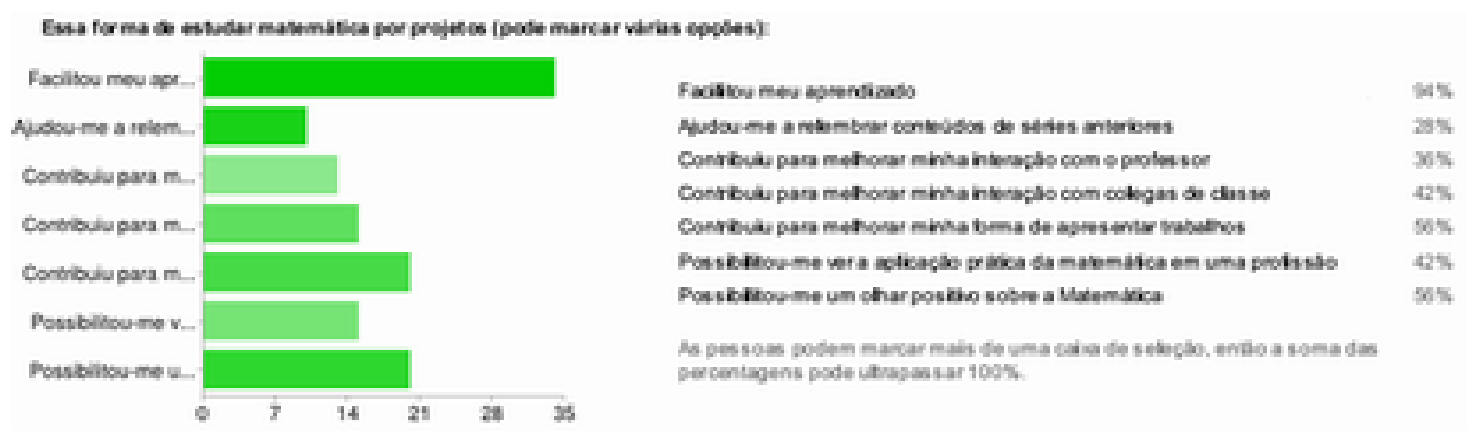

Fonte: 0 autor (2012).

A aprendizagem baseada em projetos pode ajudá-lo como professor a criar uma sala de aula de alto desempenho em que você e seus alunos formam uma comunidade de aprendizagem poderosa focada na realização, no autodomínio e na contribuição para a comunidade (MARKHAM et al, 2008).

O Gráfico 13 mostra que $92 \%$ dos alunos gostariam que essa forma de trabalho fosse aplicada em outros conteúdos ou outras disciplinas, o que demonstra sua grande aceitação. 
Gráfico 13. Interesse dos alunos em ter esta forma de trabalho em outras disciplinas Vocé gostar ia que esta forma de tr abalho fosse utilizada em outros conteúdos ou outras disciplinas?

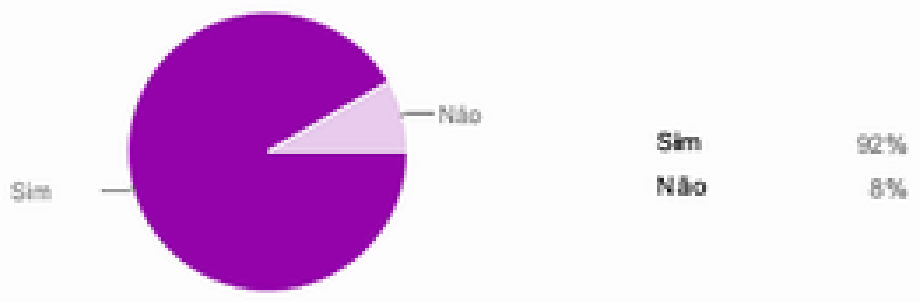

Fonte: 0 autor (2012).

O Gráfico 14 mostra que, em uma escala de 1 a 5 de participação, temos que 89\% dos alunos consideram suas participações como quatro ou cinco. Essa participação positiva também foi constatada pelo professor durante as aulas. Como citam Markham e outros (2008, p. 18), essa é uma das características deste tipo de projetos que "reconhecem o impulso para aprender, intrínseco dos alunos, sua capacidade de realizar trabalho importante e a necessidade de serem levados a sério, colocando-os no centro do processo de aprendizagem".

Gráfico 14. Autoavaliação dos alunos em relação à participação no projeto

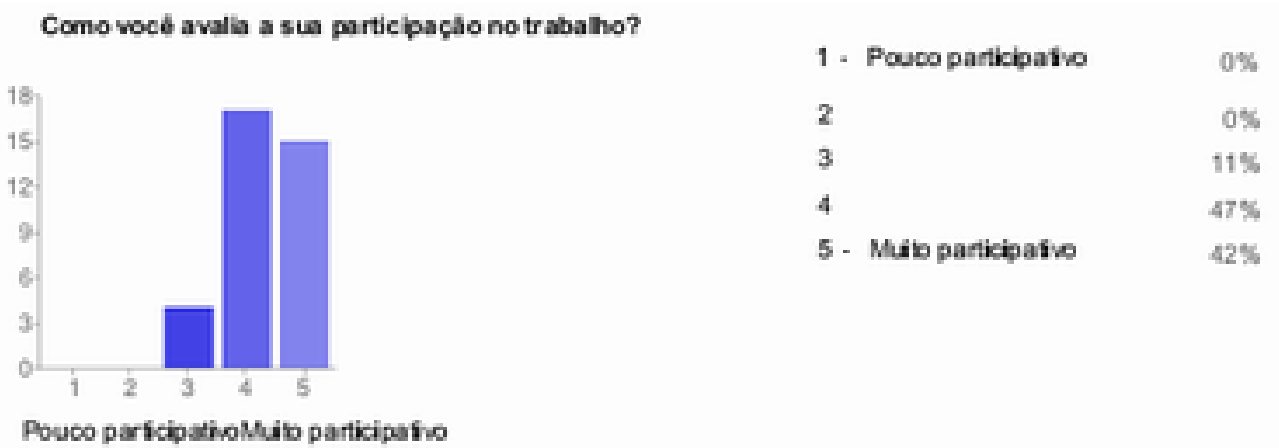

Fonte: 0 autor (2012).

O Gráfico 15 mostra a autoavaliação dos alunos em Trigonometria do triângulo retângulo. Por essa avaliação, a média da turma foi 7,2 em uma escala de zero a dez, bem próxima da média real da turma que, como vimos na Erro! Fonte de referência não encontrada., foi de $75 \%$.

Gráfico 15. Autoavaliação do aprendizado em trigonometria 


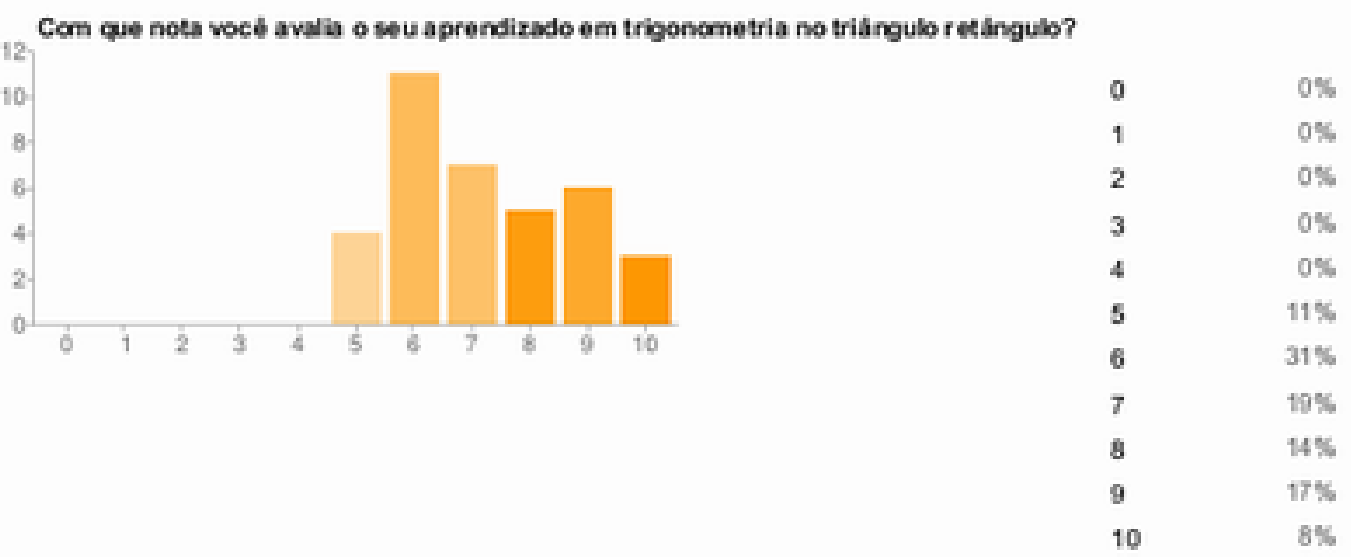

Fonte: 0 autor (2012).

O Gráfico 16 mostra a auto avaliação dos alunos em áreas de figuras planas. Por essa avaliação, a média da turma foi 7 em uma escala de zero a dez, essa média também está próxima da média real da turma.

Como citam Markham e outros (2008, p. 18), os projetos "utilizam avaliações baseadas em desempenho que comunicam altas expectativas, apresentam desafios rigorosos e requerem uma séria de habilidades e de conhecimentos". Com isso, os alunos que passam por essa experiências acabam tendo um desempenho melhor, reflexo do seu maior aprendizado. Outra questão importante destacada por esses autores, é que enquanto a abordagem tradicional, baseada apenas em aulas expositivas, muitas vezes não consegue atingir a muitos alunos, a aprendizagem baseada em projetos "atende as necessidades de aprendizes com diferentes níveis de habilidade e estilos de aprendizagem" (MARKHAM et al., 2008, p. 20).

Gráfico 16. Autoavaliação dos alunos em áreas de figuras planas 


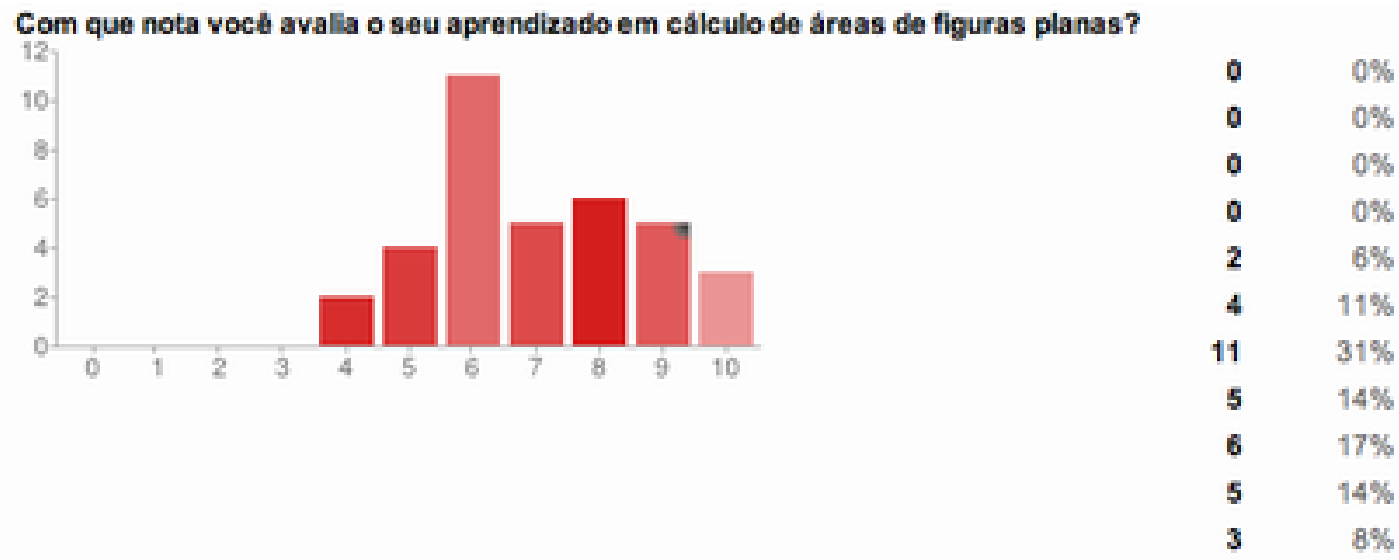

Fonte: 0 autor (2012).

\subsubsection{Algumas melhorias observadas}

No decorrer deste projeto conseguimos observar várias melhorias, algumas das quais discutiremos aqui.

\section{Maior aprendizado dos conteúdos pelos alunos}

Em diversas situações da vida escolar, muitos dos alunos do presente trabalho ficavam desesperados ou não faziam trabalhos que envolvessem apresentações para outros. Porém, nesse projeto, desde o início os alunos se empenharam e procuraram cumprir praticamente tudo que era combinado. Para a maioria, a apresentação passou de uma tarefa complicada ou indesejada, para uma tarefa simples e gratificante. Alguns alunos apresentavam mais do que era pedido. Grupos que antes levavam em média 15 minutos nas apresentações, devido a uma pesquisa de baixa qualidade, melhoraram bastante a forma de pesquisar e com isso, uma aula de 50 minutos já não estava sendo suficiente para a apresentação do grupo.

As atividades práticas mostravam constantemente a relação entre os conceitos matemáticos e suas aplicações. Os alunos passaram a fazer perguntas que nas turmas anteriores não faziam. 0 que mostra que tais atividades práticas e as apresentações os levaram a desequilíbrios cognitivos. Esses desequilíbrios levaram a posteriores dúvidas e essas dúvidas levaram ao aprendizado, muitas vezes antes mesmo do momento em que o professor iria consolidar os conteúdos abordados de forma expositiva. Podemos ver essa observação, também, na fala de um aluno: 
"As apresentações do trabalho também foram ótimas, adquirimos um conhecimento antecipado. Nas horas em que o professor explicava a matéria, já era mais fácil."

Com isso, como podemos notar nas tabelas 1 e 2 , os alunos passaram a ter desempenho melhor em todas as avaliações, tanto no comparativo com turmas anteriores como com os resultados da própria turma em trimestres anteriores, sem a aplicação do projeto. Esse melhor resultado também foi percebido pelos próprios alunos, o que foi explicitado em suas autoavaliações dos conteudos trabalhados (gráficos 15 e 16).

Em questões semelhantes às da Figura 6 , que pode ser resolvida aplicando-se duas vezes a tangente, alguns alunos conseguiram perceber que se traçarmos uma perpendicular em relação ao segmento HJ (seja $\mathrm{M}$ a intesecção) passando pelo ponto $\mathrm{K}$, podemos determinar o segmento MK, usando seno de 26․ Usando o fato que a soma dos ângulos internos de um triângulo qualquer é sempre $180^{\circ}$, podemos determinar os ângulos internos de qualquer triângulo, daí só aplicarmos a relação trigonométrica adequada.

Figura 6. Problemas trigonométricos mais avançados.

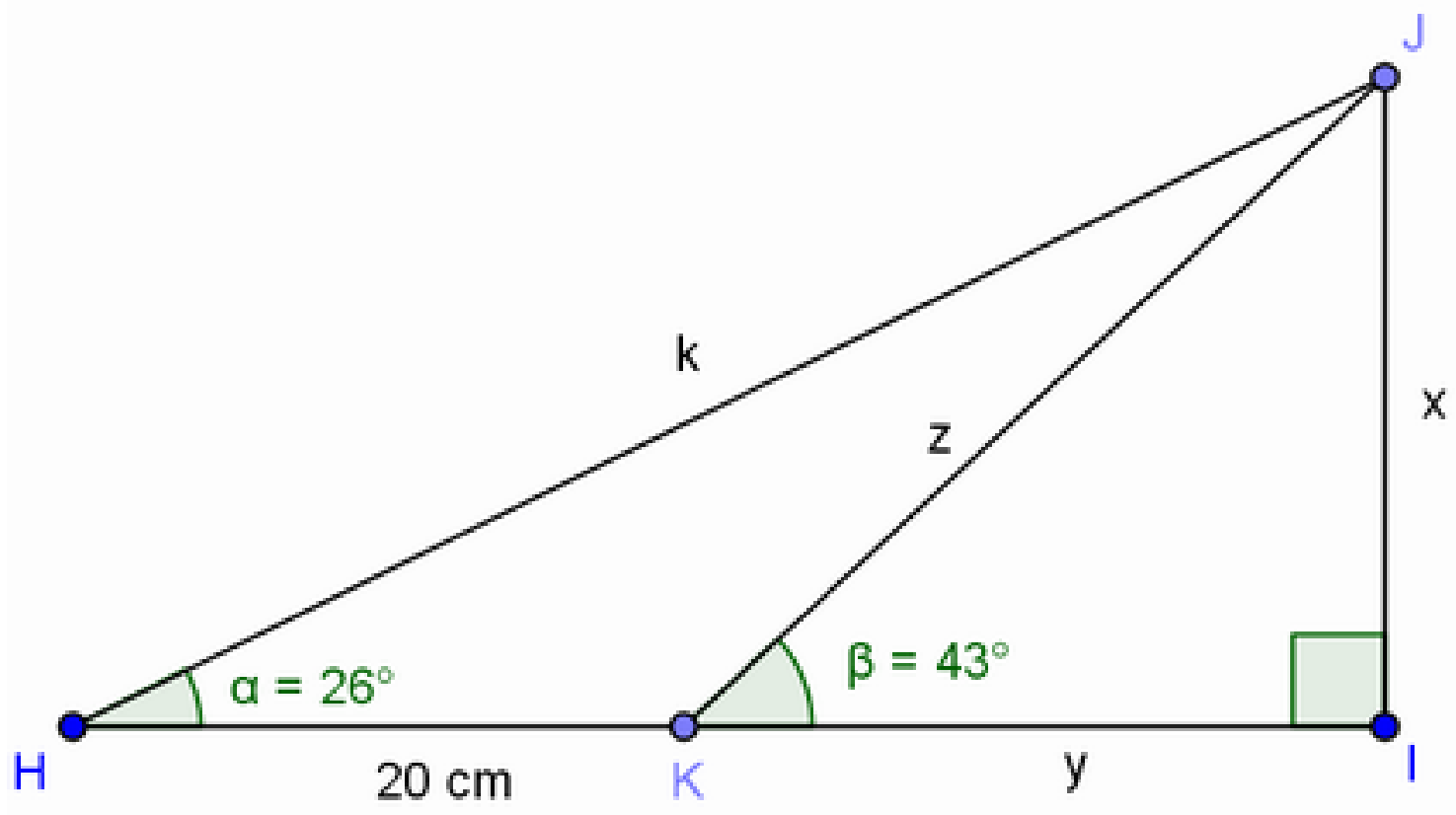

Fonte: O autor (2012). Elaborado na ferramenta Geogebra. 
Essa percepção de resolver questões de formas não comuns, para turmas anteriores ou para a própria turma em trimestres sem o projeto, também foi notada em outros momentos, principalmente quando se exigia um conhecimento mais aprofundado do conteúdo. Conforme Markham e outros (2008, p. 19), a aprendizagem baseada em projetos "leva a um desenvolvimento cognitivo de nível superior por meio do envolvimento dos alunos em problemas novos e complexos". 


\section{Maior participação e interesse dos alunos}

Houve compromisso e participação de quase todos os alunos no decorrer do projeto. Além da participação na escola, eles passaram a estudar mais em casa, a utilizar o livro didático e a fazer pesquisas. Antes os livros eram esquecidos por muitos alunos (ou não traziam por falta de interesse) e suas atividades resolvidas por poucos. Como mostra a fala do aluno abaixo, em seu relatório:

"Eu principalmente, que não prestava atenção em nenhuma aula, fiquei mais atento às aulas e aprendi muitas coisas."

Ficou perceptível que grande parte dos alunos estava estudando além do seu horário habitual na escola e conseguindo criar bases que facilitariam a aprendizagem dos conteúdos. Isso se confirmou por meio dos relatórios escritos pelos alunos, onde foram destacadas várias frases como:

"Algumas noites que fiquei até quase uma da manhã realizando os cálculos e no outro dia tinha que acordar cedo para ir à casa da pessoa X pra continuar o trabalho."

"Esse trabalho exigiu muito de cada um dos componentes do grupo, foi um trabalho que tivemos que dar o nosso melhor."

Outra observação importante foi que alguns alunos tímidos, que anteriormente quase não participavam, conseguiram superar esse bloqueio durante a realização das atividades e nas apresentações do trabalho ou dos conteúdos pesquisados. Também, como já citado, os alunos passaram a realizar tarefas solicitadas pelo professor (exercícios, pesquisas, apresentações etc.), o que muitos não faziam antes.

\section{Maior valorização da Matemática}


A Matemática deixou de ser vista para os alunos como uma matéria "chata" e "sem utilidade" e passou a ser detentora de um olhar representativo de um campo maior do que as quatro operações básicas ou a tabuada, uma ciência necessária no dia a dia das pessoas, tanto para quem depende dela diretamente ou indiretamente. As críticas negativas em relação à disciplina foram perdendo espaço à medida em que o projeto avançava. Com isto, as tentativas em convencer o professor de pular conteúdos ou falar sobre outros assuntos para fugir do compromisso de estudar e participar da matéria, foram substituídos pelo interesse em aprender.

"Aprendi que a matemática não é tão insuportável, como eu imaginava."

"Aprendi que a matemática é a base de tudo, mesmo a gente não querendo usá-la."

\section{Melhoria no trabalho em grupo}

Antes do projeto, os alunos não se dedicavam muito na execução dos trabalhos. Pesquisavam pouco e passavam informações decoradas durante as apresentações, ficando evidente que eles estavam mais preocupados em terminar o que haviam decorado do que aprendizado. Muitas vezes se perdiam quando era feito uma pergunta pelo professor ou pelo colega de classe. $\mathrm{O}$ fato de esse projeto começar com uma escolha livre de profissão fez que todos os alunos se aproximassem um dos outros a partir de um interesse em comum. O tempo dado em sala de aula para que os próprios colegas de grupos debatessem sobre a profissão escolhida e organizassem a condução do trabalho fez com que os componentes de cada grupo tivessem uma responsabilidade maior na hora da pesquisa e das apresentações.

Essa forma de agir dos alunos persistiu durante todo o projeto. A cada apresentação eles se soltavam mais, passavam a colaborar mais um com o outro e, com o tempo, apresentar ou trabalhar em grupo, passou a ser uma rotina de fácil execução para quase todos. Com isso, os grupos passaram a ser mais criteriosos em relação aos resultados das pesquisas encontradas. 0 que melhorou bastante as apresentações e o aprendizado. 
A relação positiva entre os componentes dos grupos facilitava, inclusive, na adaptação de alunos novatos (oriundos de outras escolas). Quando o professor ia explicar o funcionamento do trabalho, por exemplo, percebia que esses novos alunos já tinham informações que foram obtidas através dos colegas de classe. Restava para o professor confirmar se as informações estavam corretas e incluir esse aluno em um dos grupos. Após estarem em um grupo, eles rapidamente se adaptavam ao ritmo do mesmo para execução do trabalho que estava sendo realizado, o que não era facilmente observado nas turmas anteriores, onde a adaptação era mais lenta.

Concordamos com Markham e outros (2008, p. 20) quando defendem que um dos benefícios da aprendizagem baseada em projetos é que ela "cria comunicação positiva e relações cooperativas entre diferentes grupos de estudantes", o que possibilita que os alunos não apenas aprendam sozinhos, como também aprendam juntos, na relação com o outro, e, como diria Freire, enquanto aprende, ensina e enquanto ensina, aprende. Possibilita, assim, a constituição de comunidades de aprendizagem dentro e fora do ambiente escolar.

\subsubsection{Dificuldades que persistem}

Para a maioria dos alunos, os conteúdos considerados de nível fácil ou mediano eram compreendidos em quase sua totalidade. Em turmas anteriores, boa parte desses conhecimentos não eram bem assimilados.

Porém, apesar de uma melhoria significativa nas turmas do presente estudo de caso, alguns alunos ainda permaneceram com dificuldades de interpretação e resolução de problemas mais complexos. Por exemplo, os que exigiam a aplicação simultânea do conhecimento de três ou mais conteúdos matemáticos e alguns cálculos sobre áreas sombreadas (envolvendo polígonos inscritos ou figuras internas).

\section{CONSIDERAÇÕES FINAIS}

A disciplina de Matemática é muitas vezes questionada, principalmente pelos alunos, sobre a sua aplicação e o número de aulas (consideradas excessivas) que há, semanalmente, nas turmas do 
ensino fundamental: "Para que serve ou onde irei usar isto? Não entendi nada, não existe uma forma mais fácil? Explica direito 'fessor' porque eu não estava prestando atenção". Essas e outras situações são comuns no dia a dia de quem ensina matemática.

Este trabalho buscou, por meio de um projeto prático envolvendo uma profissão, tirar o aluno de um papel passivo no processo de ensino-aprendizado, tornando-o ativo na construção de seu conhecimento. Os alunos tiveram que buscar os conteúdos matemáticos e suas aplicações, explicar o que haviam entendido por meio de apresentações e, principalmente, utilizar tais conhecimentos na prática. Dessa forma, começaram a perceber que o número de aulas semanais poderia ser até maior. Essas tarefas aos poucos foram transformando a turma.

Os alunos se viram em uma situação em que aprender os conteúdos era importante. À medida em que o projeto avançava, eles ficavam mais motivados em aprender novos conteúdos matemáticos. Isso facilitou para que o professor pudesse identificar a zona de desenvolvimento proximal (ZDP) (VYGOTSKY, 1994) e, consequentemente, apoiá-los para que pudessem atingir a zona de conhecimento real (ZDR), ou seja, consolidar os novos conhecimentos que estavam sendo trabalhados, seja por intermédio do próprio professor ou dos colegas.

Este projeto também promoveu um resgate de conteúdos que haviam sido abordados em séries anteriores, abrindo oportunidades de aplicação dos conteúdos aprendidos e para a utilização de materiais concretos como: a construção de maquetes, plantas baixas, teodolito artesanal, uso de transferidor, trena, informática, visita de campo e aulas extraclasse. Conseguiu, também, ampliar o interesse dos alunos na disciplina de matemática. As pesquisas, as apresentações e a percepção da aplicabilidade melhoraram a capacidade de aprendizado, tornando os alunos mais exigentes e questionadores em relação aos conteúdos abordados.

Outro fator observado foi a aproximação entre os alunos e entre estes e o professor. Havia uma liberdade e interação positivas durante as execuções das atividades, o que permitiu com que todos pudessem sanar suas dúvidas, tanto com o colega, professor ou pessoas externas que tinham condições de responder. Além da percepção do professor, a melhoria no desempenho dos alunos ficou visível nas notas obtidas em provas, trabalhos e participação/comportamento/ 
atitude. O que, também, foi explicitado por eles próprios em seus relatórios e na avaliação do projeto. Além disso, os alunos tornaram-se mais responsáveis não só com a disciplina de matemática, como também com outras, o que reduziu bastante o número de reprovados.

Apesar dos bons resultados obtidos, melhorias poderiam ser realizadas na execução de projetos futuros. Por exemplo, poder-se-ia desenvolver um trabalho multidisciplinar ou interdisciplinar, algo que não foi conseguido neste projeto, apesar de ter havido uma tentativa do professor de matemática em executar partes do mesmo em conjunto com a disciplina de artes. Porém, a professora não se mostrou interessada, pois, segundo ela, não trabalhava com figuras geométricas.

O projeto, também, limitou-se a explorar apenas alguns conteúdos matemáticos da $8^{a}$ série do ensino fundamental, o que poderia ser expandido para outros conteúdos desta e de outras séries. É válido destacar ainda, que apesar deste trabalho ter focado na aprendizagem baseada em projetos, as aulas expositivas continuaram a acontecer. Mas, ao contrário do que ocorre convencionalmente, em que primeiro o professor expõe o conteúdo da disciplina, para depois os alunos aplicarem-no de alguma forma, como por meio de exercícios, aqui a situação foi inversa: primeiro os alunos pesquisavam, construíam, chegavam às duvidas, sanavam algumas durante esse processo e apenas depois, ou no decorrer, o professor realizava aulas expositivas. Assim, essas aulas ajudavam a reforçar conceitos, a sanar dúvidas, a consolidar ou complementar o aprendizado, ao invés de ser um primeiro contato dos alunos com o conteúdo.

Isso não significa defender a ideia de que a aprendizagem baseada em projetos deva ser aplicada para todos os conteúdos e a todo momento ou que se trata de um método superior e que os demais devam ser extintos, mas tão somente que este é um recurso muito interessante, que se bem utilizado, nos momentos adequados, pode trazer diversos benefícios, de forma a complementar o processo de ensino-aprendizagem.

\section{REFERÊNCIAS}


BOCK, A. M. B.; FURTADO, O.; TEIXEIRA, M. L. T. Psicologias - Uma introdução ao estudo de Psicologia. 14ạ ed., São Paulo: Saravia, 2008.

CANDAU, Vera Maria. Reinventar a escola. Rio de Janeiro, Vozes, 2000.

D’AMBROSIO, Ubiratam. Educação matemática da teoria a prática. 16ạ edição. Papirus: São Paulo, 2009.

FÁVERO, Rutinelli da Penha; NUNES, Vanessa Battestin. Os projetos de aprendizagem e as TICs. In: Informática na Educação: Um Caminho de Possibilidades e Desafios. 1a ed. Vitória: Instituto Federal de Educação, Ciência e Tecnologia, 2011, p. 161-186.

FREIRE, Paulo. Extensão ou Comunicação. 7. ed. Rio de Janeiro: Paz e Terra, 1983.

FREIRE, Paulo. Pedagogia do Oprimido. 11. ed. Rio de Janeiro: Paz e Terra, 1987.

FREIRE, Paulo. Pedagogia da autonomia: saberes necessários à prática docente. 12. ed. São Paulo: Paz e Terra, 1996.

GIL, Antonio Carlos. Como elaborar projetos de pesquisa. São Paulo: Atlas. 4ạ ed, 2002.

HUBER, M. Apprendre en projets: la pédagogie du projet-élèves. Chronique Sociale, Lyon, 1999.

INEP. Programa Internacional de Avaliação de Alunos - PISA. Brasília, 2003. Disponível em: http:/ /www.inep.gov.br/internacional/pisa/ Acesso em: 19/08/2009.

MARKHAN, Thom; LARMER, John; RAVITZ, Jason (orgs). Aprendizagem baseada em projetos: guia para professores do ensino fundamental e médio. Buck Institute for Education; Tradução Daniel Bueno, 2a. ed., Porto Alegre: Artmed, 2008.

PCN. Parâmetros Curriculares Nacionais. MEC, 1998.

PIAGET, Jean. A tomada de consciência. São Paulo: Melhoramentos; Edusp. 1977.

PIAGET, Jean. Seis estudos de psicologia. 19. ed. Rio de Janeiro: Forense Universitária, 1993.

SOLÉ, Isabel. Disponibilidade para a aprendizagem e sentido da aprendizagem. In: 0 construtivismo na sala de aula. 6ạ edição. Ática: São Paulo, 2003.

SUGIMOTO, Luiz. Mapeando a motivação dos alunos. Secretaria de Ensino Superior - Governo do Estado de SP. São Paulo, 2009. Disponível em: < http://www.ensinosuperior.sp.gov.br/sis/ lenoticia.php?id=1119>. Acesso em: 25/08/2009.

VYGOTSKY, Lev Semyonovitch. A formação social da mente: o desenvolvimento dos processos psicológicos superiores. 5a ed. São Paulo: Martins Fontes, 1994. 